\title{
Kas-iskelet sistemi enfeksiyonlarında nükleer tıp ve görüntüleme
}

\author{
Nuclear medicine and imaging in musculoskeletal infections
}

\author{
Özlem Şahin, Mustafa Serdengeçti, Ömer Uğur \\ Necmettin Erbakan Üniversitesi, Meram Tıp Fakültesi, Nükleer Tıp Anabilim Dalı, Konya
}

Kas-iskelet sistemi enfeksiyonlarının tanı ve tedavisi patofizyolojik özellikleri nedeniyle güçtür. Teşhiste kullanılan çeşitli radyolojik ve radyonüklid görüntüleme yöntemleri vardır. Ancak tüm testlerin kendilerine ait kısıtlılıkları vardır. Kullanılan görüntüleme yöntemleri yerel tecrübeye, tekniklerin ulaşılabilirliğine ve maliyetlere göre merkezler arasında farklılıklar gösterir. Nükleer tıp yöntemleri daha anatomik değişiklikler oluşmadan önce fonksiyonel ve metabolik mekanizmalarla enfeksiyon ve enflamasyon odaklarının saptanmasına imkan verir. Üç fazlı kemik sintigrafisi kolay ulaşılabilirliği, ucuz olması ve yüksek duyarlılığı nedeni ile kas-iskelet sistemi enfeksiyonlarında en çok kullanılan nükleer tıp yöntemlerinden biridir. Galyum-67 sintigrafisi günümüz pratiğinde kendine sadece spondilodiskit tanısında yer bulmaktadır. İşaretli lökosit sintigrafisi vertebral enfeksiyonlar dışındaki diğer kas-iskelet sistemi enfeksiyonlarında halen en değerli görüntüleme yöntemi olmaya devam etmektedir. Son yıllarda kılavuzlara giren standartlaştırılmış görüntüleme ve değerlendirilme protokollerinin kullanımının yaygınlaşması ile tanısal doğruluğunun daha da artması beklenmektedir. Şüpheli durumlarda tamamlayıcı kemik iliği sintigrafisi gerekebilir. Antigranülosit monoklonal antikor veya antikor fragmanları ile işaretli lökosit sintigrafis ile benzer doğruluk oranları elde edilmiş olsa da onların da kendi kısıtlılıkları vardır. Planar görüntülere SPECT/BT'nin eklenmesi sintigrafik yöntemin hassasiyetini ve özgüllüğünü artırır. FDG PET ve FDG PET/BT'nin kas-iskelet sistemi enfeksiyonlarının tanısındaki değeri son yıllarda çok sayıda çaIışma ile araştırılmış ve araştırılmaya devam etmektedir. Diğer alanlarda FDG PET'in yeri hala tartışmalı olsa da spinal osteomiyelitlerdeki net yararı kabul edilmiştir. Çok yakın zamanda kullanıma giren PET/MRG'nin mükemmel anatomik ve yumuşak doku görüntüleme kapasitesi ve moleküler PET bilgisini birleştirerek diğer tüm yöntemlerin eksikliklerinin üstesinden gelmesi beklenmektedir.

Anahtar sözcülkler: osteomiyelit; FDG PET; SPECT/BT; PET/BT; spondilodiskit; diyabetik ayak; işaretli lökosit
Diagnosis and treatment of musculoskeletal infections are difficult due to their pathophysiological features. There are various radiological and radionuclide imaging methods used in diagnosis. However, all tests have their own limitations. The imaging methods used differ between centers according to local experience, techniques availability and costs. Nuclear medicine methods allow detection of infection and inflammatory foci with functional and metabolic mechanisms before anatomical changes occur. Three-phase bone scintigraphy is one of the most widely used nuclear medicine methods in musculoskeletal infections due to its easy accessibility, cheapness and high sensitivity. Gallium-67 scintigraphy is used only to diagnose spondylodiscitis in today's practice. Labeled leukocyte scintigraphy remains the most valuable imaging modality in musculoskeletal infections except vertebral infections. Diagnostic accuracy is expected to increase thanks to the widespread use of standardized imaging and evaluation protocols which are included in the guidelines in recent years. Complementary bone marrow scintigraphy may be required in suspicious cases. Although accuracy ratios were obtained similar to leukocyte scintigraphy labeled with antigranulocyte monoclonal antibody or antibody fragments, they also have their own limitations. Adding SPECT/CT to the planar images increases the sensitivity and specificity of the scintigraphic methods. The value of FDG PET and FDG PET/CT in the diagnosis of musculoskeletal infections has been investigated in recent years and continues to be investigated. Although the role of FDG PET in other areas is still controversial, its net benefit in spinal osteomyelitis has been recognized. The recently introduced $P E T / M R I$ is expected to overcome the shortcomings of all other methods by combining excellent anatomical and soft tissue imaging capacity and molecular PET knowledge.

Key words: osteomyelitis; FDG PET; SPECT/CT; PET/CT; spondylodiscitis; diabetic foot; labeled leukocyte

- İletişim adresi: Dr. Özlem Şahin, Necmettin Erbakan Üniversitesi, Meram Tıp Fakültesi, Eski Yerleşke, D Blok Nükleer Tıp Anabilim Dalı, Meram, Konya Tel: 0505 - 2401292 e-posta: drozlemsahin@gmail.com

- Geliș tarihi: 25 Mayıs 2020 Kabul tarihi: 23 Haziran 2020 
as-iskelet sistemi enfeksiyonları, anatomik ve patofizyolojik özelliklerinden dolayı diğer vücut bölgelerindeki enfeksiyonlara oranla daha düşük tedavi başarısına sahiptir. Tedavi genellikle uzun zaman, çok sayıda ameliyat, bazen de amputasyon gerektirir. Ayrıca enfeksiyonun hematojen yayılması sepsis gibi hayatı tehdit eden durumlara neden olabilir. Bu nedenle uygun tedaviye bir an önce başlamak ve ciddi komplikasyonlardan kaçınmak için enfeksiyonun mümkün olan en kısa sürede ve doğru olarak tespit edilmesi gerekmektedir. Ancak özellikle düşük dereceli, kronik enfeksiyonlarda, ameliyat sonrası alanlarda ve kompleks anatomisi olan bölgelerde tanı güçleşmektedir.

Kas-iskelet sistemi enfeksiyonları tanısında yeterince yüksek tanısal doğruluğa sahip tek bir rutin test olmaması nedeni ile teşhis çoğunlukla klinik, laboratuvar, mikrobiyolojik ve görüntüleme testlerinin ortak değerlendirilmesi ve kişisel deneyimle konulabilmektedir. Rutin pratikte kullanılan çok sayıda görüntüleme yöntemi olsa da her yöntemin kısıtlılıkları vardır. Görüntüleme teknikleri merkezin deneyimlerine, tekniklerin ulaşılabilirliğine ve maliyetlere göre uygulanan merkezlerde farklılık gösterir.

Geleneksel radyografiler anatomik olarak genel bir bakış açısı sunarak sonraki prosedürün belirlenmesine rehberlik ettiğinden genellikle ilk tercih edilen görüntülemelerdir. Ancak genellikle \%30-50 kemik kaybı olunca radyolojik olarak pozitif hale geldiğinden erken tanı mümkün değildir. ${ }^{[1]}$ Bilgisayarlı tomografi (BT) kompleks anatomi bölgelerinde direkt grafilerden daha yararlıdır ancak kronik osteomiyelitte tanısal değeri sınırlıdır. Manyetik rezonans görüntüleme (MRG)'nin enfeksiyonu dışlamada negatif öngörü değeri çok yüksektir. Ancak anormal kemik iliği sinyaline neden olabilecek diğer patolojileri enfeksiyondan ayırt etme kabiliyeti yani pozitif öngörü değeri daha düşüktür. Ayrıca metalik implantlar kullanımını sınırlar. Ultrasonografi, osteomiyelit için primer bir görüntüleme yöntemi değildir ancak MRG'nin kontrendike olduğu durumlarda ve ortopedik materyalleri bulunan hastalarda yararlı olabilir. ${ }^{[2]}$

Nükleer tıbbın alanına giren radyofarmasötiklerle elde edilen fonksiyonel ve metabolik görüntüleme yöntemleri, daha anatomik değişiklikler oluşmadan hastalığın tanınmasına imkân sağlar. Ancak anatomik ayrıntıların bilinmemesi nedeni ile fizyolojik ve patolojik süreçler birbirinden ayrılamayabilir. Son yıllarda tek foton emisyon bilgisayarlı tomografi/bilgisayarlı tomografi (SPECT/BT) ve pozitron emisyon tomografi/bilgisayarlı tomografi (PET/BT)'nin kullanıma girmesi ile fonksiyonel ve morfolojik bilgi tek bir cihaz ve görüntüleme ile elde edilebilmektedir. Bu hibrit görüntüleme yöntemleri ile radyofarmasötik tutulumunun tam olarak lokalizasyonu yapılabildiğinden teşhis güvenilirliğinde ve test doğruluğunda önemli gelişmeler sağlanmıştır. ${ }^{[3]}$

\section{RADYONÜKLID GÖRÜNTÜLEME}

Nükleer tıp, kas-iskelet sistemi enfeksiyonlarının teşhis ve karakterizasyonunda onlarca yıldır önemli bir rol oynamıştır. Benzersiz fonksiyonel görüntüleme yöntemlerinin yanında tüm vücudu görüntüleyebilmesi nükleer tıp testlerinin önemli yönleridir. Klinik öncesi ve klinik çalışmalarda enflamatuvar yanıtın farklı aşamalarını gösteren birçok radyofarmasötik üzerinde çaIışılmış, ancak bunlardan sadece birkaç tanesi rutin klinik kullanıma geçebilmiştir. Ancak bu alandaki yoğun çalışmalara rağmen halen enfeksiyon ve enflamasyon ayrımını tam olarak yapabilecek bir radyofarmasötik geliştirilememiştir. ${ }^{[4]}$

İdeal enfeksiyon radyofarmasötiğinden beklenenler; enfeksiyon alanlarında hızlı ve yüksek konsantrasyonda tutulması, uygun süre retansiyon göstermesi, enfekte olmayan dokudan hızla temizlenerek yüksek hedef/zemin aktivite oranı sağlaması, fizyolojik organ tutulumlarının, kan ve kas tutulumunun düşük olması, enfeksiyon ve steril enflamasyonu ayırt edebilmesi, bakteriyel, viral ve fungal enfeksiyonları ayırt edebilmesi, immun yanıt veya farmakolojik etki oluşturmaması, radyasyon maruziyetinin düşük, maliyetinin az, temininin ve uygulanmasının kolay olmasıdır. ${ }^{[4]}$

\section{Üç Fazlı Kemik Sintigrafisi}

Üç fazlı kemik sintigrafisi (ÜFKs), kas-iskelet sistemi enfeksiyonlarının tanısında en yaygın olarak kullanılan radyonüklid görüntüleme yöntemidir. Tc-99 m ile işaretli difosfonatlar (metilen difosfonat ve hidroksi metilen difosfonat) ile uygulanır. Tutulum mekanizması, difosfanatların amorf kemik mineral matriksini oluşturan hidroksiapatit kristallerine fizikokimyasal adsorpsiyon ile bağlanması şeklindedir. Radyofarmasötiğin kemik yapıda tutulum miktarı, bölgesel kan akımı ve osteoblastik aktivite ile ilişkili olarak yeni kemik oluşumuna bağlıdır. ${ }^{[5]}$ illk faz dinamik 'perfüzyon' fazı, ikinci faz ise perfüzyonun hemen ardından alınan statik görüntü 'kan havuzu' fazıdır. Üçüncü faz olan 'iskelet' fazı 2-4 saat sonra ilgili alandan elde edilir. Osteomiyelitte üç fazda da artmış radyoaktivite tutulumu gözlenir. Yumuşak doku enfeksiyonlarında ilk iki fazda tutulum mevcutken iskelet fazında tutulum olmaz. Kemik yapıyı tutan dejeneratif patolojiler gibi non-enfeksiyöz patolojilerde ise iskelet fazında tutulum olurken perfüzyon ve kan havuzu fazında normal bulgular izlenir. ÜFKs kas-iskelet sistemi enfeksiyonlarını göstermede yüksek duyarlılığa sahiptir (tutulum yoksa enfeksiyon yoktur). Ancak osteoblastik aktivite kırık, geçirilmiş cerrahi, malignite, protez gevşemesi, metabolik kemik hastalığı 
gibi birçok durumda da artış gösterdiğinden özgüllüğü düşüktür. Kalça eklemi protezlerinden sonra en az iki yıl, diz eklemi protezlerinden sonra beş yıl kemik yapıda remodeling devam ettiğinden kemik sintigrafisi pozitif olabilir. Enfeksiyon olasılı̆̆ düşük hastalarda tarama yöntemi olarak kullanışlıdır. ${ }^{[6]}$

\section{Galyum-67 Sintigrafisi}

Uzun yıllar kas-iskelet sistemi enfeksiyonlarında başıca görüntüleme yöntemi olmasına rağmen günümüzde neredeyse sadece omurga enfeksiyonlarının tanısında kullanılmaktadı. ${ }^{[6]}$ Enfeksiyonda Galyum-67 (Ga-67) tutulum mekanizması multifaktöriyeldir. Enjekte edilen Ga-67'nin \%90'ı transferrine bağlı olarak plazmada bulunur. Enfeksiyonla birlikte kan akımı ve vasküler permabilitenin artmasıla Ga-67 birikimi olur. Ga-67 enflamatuvar eksüdalarda ve nötrofillerde yüksek konsantrasyonda bulunan laktoferrine yüksek afiniteyle bağlanır. Ayrıca Ga-67'nin enfekte dokularda bakteriler tarafindan sideroforlarla hücre içine alındığı gösterilmiştir. ${ }^{[7]}$

Görüntüleme genellikle enjeksiyondan 48-72 saat sonra yapılır. Osteomiyelitte başarılı tedavi sonrasında, protez gevşemelerinde, kırık veya ortopedik girişim alanlarında kemik onarım bölgelerinde Ga-67 uptake'i olması şüpheli osteomiyelit hastalarında yorumlamayı zorlaştırabilir. ${ }^{[8]}$

\section{İşaretli Lökosit Sintigrafisi}

İşaretli lökosit sintigrafisi (ís) günümüzde enfeksiyon/ enflamasyonun tanısında altın standart olarak kabul edilen radyonüklid görüntüleme yöntemidir. İn vitro olarak lökositlerin işaretlenmesi In-111 (Indium-111) oxine ya da Tc-99 m HMPAO (hexamethylene propyleneamine oxime) kullanılarak yapılır. Tutulum kemotaksise, işaretlenen hücre sayısına ve türüne, enflamatuvar yanıtın hücresel bileşenine bağlıdır. İşaretlenen hücrelerin çoğunluğunu granülositler oluşturur. Bu nedenle bakteriyel enfeksiyonlarda başarı yüksekken, lenfosit infiltrasyonunun daha ağırlıklı olduğu tüberküloz gibi kronik enfeksiyonlarda etkinliği düşüktür. Lökositlerin invitro olarak işaretlenmesi nisbeten uzun, zahmetli ve kontaminasyon riski taşıyan bir işlemdir. Hastadan 40-60 mL kan alınarak yaklaşık üç saat süren bir prosedürle lökositler ayrıştırlıp işaretlendikten sonra hastaya damar yolundan geri verilir. Son yıllarda lökositleri in vitro işaretlemek için geliştirilen basit kapalı sistemler daha kolay ve kaliteli bir işaretleme sağlayabilmektedir. In-111 oxine biyo-dağııımı karaciğer, dalak ve kemik iliğine olur. Tc99 m HMPAO'da ise ek olarak üriner sistemde, kalın barsak ve safra kesesinde tutulum olur. In-111'in uzun yarı ömrü geç görüntülemeye imkân verir. Siklotronda üretilmesi nedeni ile temin güçlükleri, uygun olmayan enerji düzeyi nedeni ile rezolüsyonunun düşük olması gibi dezavantajları vardır. Tc-99 m HMPAO'nun dezavantajları ise düşük stabilitesi, 24 saatten uzun görüntü alınamaması ve üriner-barsak aktivitesini değerlendirmede güçlüklere neden olabilmesidir. Tc-99 m ile işaretleme yüksek görüntü kalitesi ile SPECT/BT'de avantaj sağlar.

İs, spondilodiskit hariç komplike osteomiyelit olgularının çoğunda tercih edilen tanısal radyonüklid testtir. Ancak enfeksiyonla birlikte normal kemik iliğinde de tutulum göstermesi yorumlamada güçlüklere neden olabilir. Sadece kemik iliğindeki tutulumu gösteren kemik iliği sintigrafisi (Kìs) ile kombine edilerek bu problem çözülebilir. İLs'de tutulum olan alanda Kis'nde tutulum olmaması enfeksiyonu gösterir. İLs/Kís'nin doğruluğu yaklaşık \%90'dır. ${ }^{[9]} \mathrm{KI}$ s, In-111 oxine ile eş zamanlı yapılabilirken Tc-99 m HMPAO ile arasında 2-3 gün olması gerekir. Tc-99 m HMPAO íLs ile 4. ve 24. saatte yapılan dual faz görüntüleme İLs/Kìs'ne alternatif olarak gösterilmiştir. ${ }^{[10]}$

Ortopedi ve travmatoloji ameliyatlarında uygulanan cihaz ve protezler kemik iliğinin yer değiştirmesine neden olarak yorumlamayı güçleştirir. ${ }^{[11]}$ Kemik iliği aspirasyonundan sonra, kemik greftinde, travmatik/dejeneratif artritte, gut artritinde, akut kırıklarda (ilk iki ay), akut kemik infarktı, yabancı cisim reaksiyonu varlığında spesifik olmayan işaretli lökosit tutulumu meydana gelebilir. ${ }^{[12]}$ Protez enfeksiyonlarında mikroorganizmalar protez çevresinde kendilerini fagositozdan koruyan biyofilm oluştururlar. Biyofilm lökositlerin enfeksiyona ulaşımını azaltır ve yavaşlatır. 24. saatte alınacak geç görüntü, işaretli lökositlerin uzun dönemde akümülasyonunu göstererek tanıya yardımcı olur. Protez uygulanmış eklem enfeksiyonlarının bu yapısı dirençli ve kronik enfeksiyonlara neden olur. Bazen de kemiğe yakın komşulukta yumuşak dokuda yoğun radyoaktivite tutulumu kemik enfeksiyonları ile karışabilir. SPECT/BT tutulumun tam lokalizasyonuna yardımcı olarak enfeksiyonun kemik yapıda mı yoksa yumuşak dokuda mı olduğunu gösterir. Spondilodiskitli hastaların \%50'sinde enfeksiyon kapsüllenerek fotopenik soğuk odaklara neden olabilir. Omurgadaki fotopenik odaklar; kompresyon fraktürü, malignite, radyoterapi veya cerrahi sonrası ve anatomik deformiteler varlığında da ortaya çıkabilir. ${ }^{[13]}$ Antibiyotik veya steroid kullanımı ve immun supresyonda da duyarlılık düşmektedir.

Antibiyotik tedavisi alan hastalarda İLs'den önce tedaviye ara verilmesi konusu tartışmalıdır. Antibiyotik kullanımının testin doğruluğunu etkilemediği savunulsa da bazı yazarlar enazından 1-2 hafta tedavinin kesilmesini veya şüpheli bir sonuç elde edilmesi durumunda iki hafta sonra testin tekrarını önerir. Karar hekimle birlikte görüşülerek klinik çerçevede hasta bazında verilmelidir. ${ }^{[14]}$ 


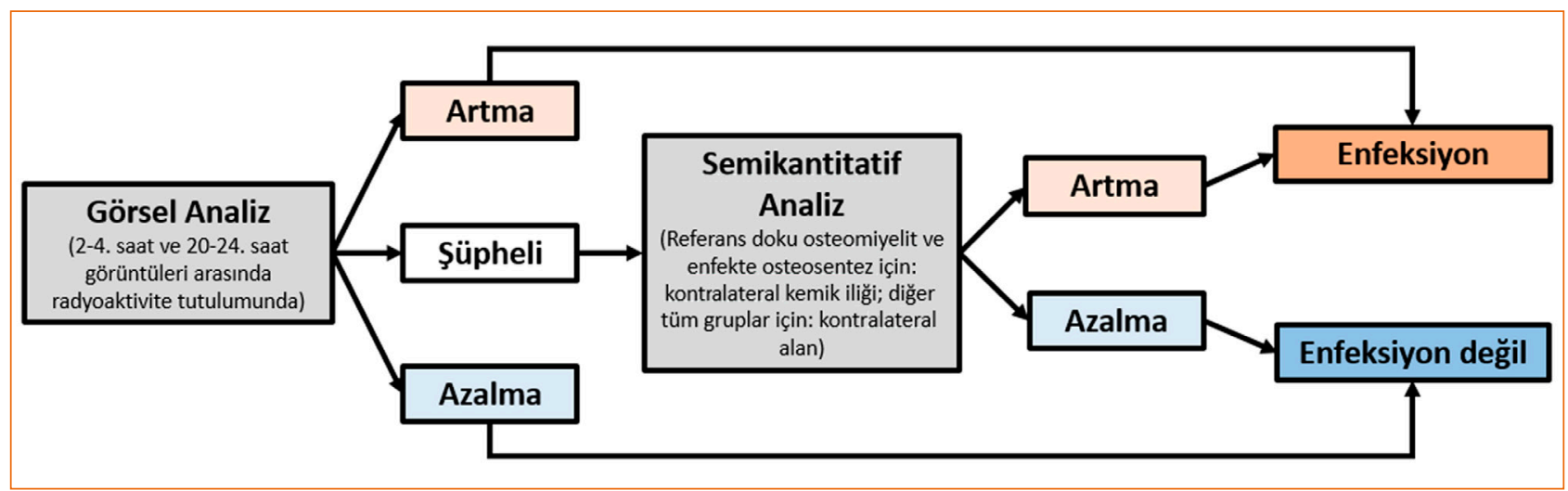

Şekil 1. İLs için önerilen, radyoizotop bozunumuna göre düzeltilmiş görüntüleme süreleri ve üç zamanlı (erken, gecikmiş ve geç) görüntüleme protokolü ile elde edilmiş görüntülerde değerlendirme akış şeması. ${ }^{[10,14]}$

Son yıllarda íss'de en iyi görüntüleme protokolü ve yorumlama kriterlerini tespit etmek için çeşitli çaIışmalar yapılmıştır. Farklı yorumlama kriterlerinden doğan farklı raporların önüne geçebilmek, yüksek kalite, özgüllük ve tekrarlanabilirliği sağlamak için standartlaştırma çalışmaları tüm dünyada devam etmektedir. EANM (Avrupa Nükleer Tıp Derneği); 2018 yılında İLs ve antigranülosit monoklonal antikor sintigrafisi'nde (AMAs) klinik endikasyonlar, görüntü elde etme, bulguları yorumlama prosedürlerini tanımlayan kılavuz yayımladı. ${ }^{[14]}$ Bu kılavuzda üç zamanlı (erken, gecikmiş ve geç) görüntüleme, radyoizotop bozunumuna göre düzenlenmiş görüntüleme süreleri ve gecikmiş ve geç görüntülerin görsel ve şüpheli durumlarda da semikantitatif değerlendirmesi tavsiye edilmektedir. 30 dakika-1. saatte yapılan erken görüntü (vasküler/kemik iliği fazı); kalite kontrol, kemik iliği dağılımı ve vasküler patern hakkında bilgi verir. 2-4. saatte yapılan gecikmeli görüntüde enfeksiyon alanında işaretli lökosit akümülasyonu olması, 20-24. saatte yapılan geç görüntüde ise zemin aktivitenin azalırken enfeksiyon alanında aktivitenin artması beklenir. Daha önceleri bu farklı zaman aralıklarında alınan görüntüleri karşılaştırabilmek için görüntü başına sabit süre veya sabit sayım alınması önerilirdi. Ancak bunun yerine EANM kılavuzunda radyoaktivitenin bozunumunu dikkate alarak, sabit değil zamana göre düzeltilmiş sürelerde görüntüleme yapılması önerilmektedir. Böylece farklı zamanlarda elde edilen görüntüler aynı ölçekte karşılaştırılarak operatör önyargısı önlenebilir. Enfeksiyonun tespiti için görsel değerlendirme genellikle yeterlidir. Ancak şüpheli durumlarda semi-kantitatif değerlendirme testin doğruluğunu artırmaktadır. Semi-kantitatif değerlendirme için enfeksiyon olduğu düşünülen alana ROi (regions of interest -ilgi alanı) çizilerek aynı büyüklükte çizilen referans ROi ile radyoaktivite tutulum oranları karşılaştırılır. 4. ve 24. saatte tespit edilen lezyon/referans doku sayım oranları karşılaştırılarak radyoaktivite tutulumundaki zamanla değişim sayısal olarak tespit edilmeye çalışılır. Bu orandaki zamanla artış enfeksiyon olduğu (lezyon/referans ${ }_{24 \mathrm{sa}}>$ lezyon/referans ${ }_{4 \mathrm{sa}}$ ), azalma ise enfeksiyon olmadığı yönünde değerlendirilir. ${ }^{[10,14]}$ íLs içinönerilen değerlendirme akış şeması Şekil 1'de sunulmuştur.

İnvitro İLs'nin uygulamasındaki kısıtlılıklar özellikle de kontaminasyon riski nedeni ile peptidler, antigranülosit antikorlar veya antikor fragmanları kullanılarak lökositlerin in vivo işaretleme teknikleri geliştirilmiştir.

\section{Human Poliklonal İmmunglobülin-G Sintigrafisi}

Nonspesifik poliklonal human immunglobulin G, antijen spesifik bir antikor olmamasına rağmen spesifik monoklonal antikorlar kadar enfeksiyon yerinde biriktiği gözlenmiştir. Human Poliklonal İmmunglobülin-G Sintigrafisi'nde (HPIGs) tutulum mekanizmasında nonspesifik ekstravazasyon ve kapiller permeabilite artışına bağlı protein sızıntısı rol almaktadır. Ig-G, In-111 ve Tc-99 m ile işaretlenebilmektedir. HPIGs'de izlenen çok yüksek vasküler tutulum ve yüksek zemin aktivite testin kısıtlılıklarını oluşturur. In-111 ile yapılan işaretlemede 48. saate kadar geç görüntüler alınarak daha yüksek hedef/zemin aktivite oranları elde edilebilir. ${ }^{[4]}$

\section{Antigranülosit Monoklonal Antikor Sintigrafisi}

Antigranülosit Monoklonal Antikor Sintigrafisi'nde (AMAs) granülositler in vitro ortama çıkarılmadan, yüzey antijenlerine karşı geliştirilen antikorlarla in vivo ortamda işaretlenir. Ticari olarak mevcut olan ürünlerden biri fare murin IgG1 monoklonal antikor olan Besilesomab'tır. Matürasyon seviyesinden bağımsız 
olarak tüm granülositlerin hücre membranlarında bulunan NCA-95 antijenine bağlanır. Tc-99 m ile yüksek verimle bağlanır. Tc99 m-Besilesomab'ın önemli bir dezavantajı tekrarlayan enjeksiyon yapılan hastaların \%30'undan fazlasında görülen ve anafilaksi riski oluşturan HAMA (human antimouse antibody) oluşumudur. ${ }^{[15]}$ Sulesomab, granülositlerdeki anti-NCA-90'a bağlanan murin IgG1 monoklonal antikorunun antijen bağlanan (Fab') parçasının fragmanıdır. Antikor fragmanları HAMA reaksiyonu oluşturmaz.

İnvivo işaretlenen antigranülosit monoklonal antikorların davranışları invitro işaretli lökositlerden farklıdır. Molekül ağırlı̆̆ı nedeni ile enflamasyon bölgesine diffüzyonu ve kandan temizlenme yavaş, zemin aktivite yüksektir. Hedef/zemin aktivite oranlarını artırmak için geç görüntüler alınmalıdır. Antikor fragmanları kullanılmasının hızlı kan klirensi, yüksek hedef/zemin aktivite oranı ve daha az immunojen olma gibi antikor kullanımına üstünlükleri vardır. ${ }^{[15]}$

\section{Kemik iliği Sintigrafisi}

Kìs'nde Tc-99 m sülfür kolloid ve nanokolloid radyofarmasötikleri kullanılır. Nanokolloid, sülfür kolloide göre daha küçük partiküllü olduğundan kemik iliğinde daha fazla tutulur. Enjeksiyonun ardından aktivite retiküloendotelial sistem tarafindan (2-4 saat) hızla kandan temizlenir. Enjekte edilen partikülün \%80-90'ı karaciğerde Kupffer hücrelerince, \%5-10'u dalakta makrofajlarca, geriye kalan kısım ise kemik iliğinde makrofajlarca fagosite edilir. Biyodağılımı İLs'ne oldukça benzerdir. Kìs, klinik rutinde İLs'nin doğruluğunu artırmak için kullanılır. Osteomiyelitte İLs'de artmış tutulum izlenirken, lökosit migrasyonunun kemik iliğini baskılaması nedeni ile Kis'nde radyoaktivite tutulumu izlenmemektedir. Aplastik anemi, myeloproliferatif hastalık ve metastazda kemik iliği radyoaktivite tutulumu artabilir. ${ }^{[16]}$

\section{Biotin Sintigrafisi}

Biotin (vitamin B7) bakteriyel bir büyüme faktörüdür. In-111 biotin esas olarak spinal enfeksiyonların görüntülenmesinde kullanılmaktadır. Kemik iliği tutulumu olmaması ve antibiyotik tedavisinin duyarlılığı etkilememesi avantajlarıdır. ${ }^{[15]}$

\section{İşaretli Antibiyotik Sintigrafisi}

Antibiyotiklerin bakteriler ile spesifik mekanizmalarla birleşmesinden yararlanılarak enfeksiyona spesifik radyofarmasötik üretimi için birçok antibiyotikle çalışıımıştır. Tc-99 m işaretli siproflaksosin en çok üzerinde çalışılan radyofarmasötik olup yapılan ilk çalışmalarda steril enflamasyonla enfeksiyonu ayırd etmede oldukça yüksek duyarlılık ve özgüllüğe sahip olduğu görülmüştür. Ancak antibiyotiklere karşı direncin zamanla artması nedeni ile son yapılan çalışmalarda özgüllükle ilgili ciddi soru işaretleri ortaya çıkmış, ayrıca aseptik enflamasyonda da yanlış pozitiflikler bildirilmiştir. ${ }^{[15,17]}$

\section{İşaretli Antimikrobiyal Peptid Sintigrafisi}

Antimikrobiyal peptidler bağışıklığın önemli bir parçası olup genlerle kodlanan doğal antibiyotiklerdir. Bakteri, virüs, mantar ve hatta kanserleşmiş hücreleri öldürebilmektedirler. Tc-99 m işaretli antimikrobiyal peptid ubiquitin (29-41) en kapsamlı çalışılmış olan antimikrobiyal peptiddir. Kas-iskelet sistemi enfeksiyonlarında yüksek duyarlılık ve özgüllüğe sahiptir; tedavi yanıtını belirlemede de ümit vermektedir. ${ }^{[15,18]}$ Peptidler antikorlara göre daha küçük moleküller oldukları için ekstravasküler boşluğa daha hızlı geçerek kandan daha hızlı temizlenir. Böylece daha düşük zemin aktivite ve daha yüksek görüntü kalitesi sağlar. ${ }^{[4]}$

\section{F-18 Florodeoksiglukoz Pozitron Emisyon Tomografisi}

F-18 Florodeoksiglukoz Pozitron Emisyon Tomografisi (F-18 FDG PET), onkoloji hastalarının tanı ve takibinde kullanımı, kapsamı ve sınırılıkları çok sayıda çalışma ile belirlenmiş, güvenilir bir moleküler görüntüleme yöntemidir. Onkolojik olguların değerlendirilmesinde en önemli problem, yanlış pozitifliklere neden olabilen enflamasyon ve enfeksiyon gibi tümör dışında artmış FDG tutulumuna neden olan patolojilerdir. FDG bu özelliği ile kas-iskelet sistemi ve diğer enfeksiyonların görüntülenmesinde umut veren bir ajan olmuştur. PET, teknik olarak sintigrafik tetkiklere göre daha yüksek bir çözünürlük sağlayan, enjeksiyondan sonra kısa görüntüleme süresi olan, kantitatif ve semikantitatif veriler elde etmeye olanak veren tomografik bir tetkiktir. Vertebra gibi kompleks anatomiye sahip alanlarda oldukça yararlı bilgiler sağlar. Yüksek duyarlılık ve negatif öngörü değerine, ancak düşük özgüllüğe sahip bir tetkiktir.

FDG, aynen glikoz gibi glikoz taşıyıcıları yoluyla hücre içine taşınarak heksokinaz ile FDG-6 fosfata fosforile edilen, ancak glikozun aksine daha fazla metabolize olmayıp hücrede akümüle olan bir glikoz analoğudur. FDG'nin enfeksiyon bölgelerinde akümülasyonu, patojen mikroorganizmalara cevaben lokalize olan enflamatuvar hücrelerde artmış tutuluma dayanır. Nötrofil ve makrofajlar başta olmak üzere metabolik olarak aktif olan bu hücrelerin sayısı, hücrelerdeki glukoz taşıyıcılarının sayısı ve FDG'ye afinitesi artmıştır. FDG küçük bir molekül olduğundan kötü perfüze olan alanlara bile hızla girer. Sadece akut bakteriyel enfeksiyonlarda değil, indolent, kronik enfeksiyonlarda ve piyojenik olmayan enfeksiyonlarda da tutulum olur. Ancak FDG sadece enfeksiyonda değil, steril enflamasyonda ve 
malign dokularda da tutulabilen nonspesifik bir radyofarmasötiktir. Ayrıca geçirilmiş cerrahi, kırık, osteofit, dejeneratif patolojilerde de artmış FDG tutulumu izlenmektedir. In-111 işaretli lökositle karşılaştırıldığında enfeksiyonu göstermede duyarlılığı benzerdir, ancak tümör dokusu ve ameliyat sonrası zeminde de tutulum olduğundan özgüllüğü daha düşüktür. [19]

$\mathrm{PET} / \mathrm{BT}$, PET'in tomografik görüntülerinin ek anatomik ayrıntı elde etmek ve atenüasyon düzeltmesi sağlamak amacıyla BT ile yazılım veya donanım olarak birleştirilmesidir. Kas-iskelet sistemi enfeksiyonlarında PET/BT'nin katkısı halen çeşitli çalışmalarla araştırılmaktadır. Aynı mantıkla geliştirilmiş PET/MRG cihazları çok yakın zamanda kullanıma girmiş olup MRG'nin mükemmel anatomik ve yumuşak doku görüntüleme kapasitesi ve kantitatif moleküler PET bilgisinin birleştirilmesi ile diğer tüm görüntüleme yöntemlerinin eksiklerinin üstesinden gelmesi beklenmektedir.

\section{F-FDG işaretli lökosit PET}

İnflamatuar hücrelerin FDG'ye afinitesinden yararlanılarak daha spesifik bir radyofarmasötik elde edebilmek için lökositler invitro ortamda FDG ile işaretlenmiştir. Yapılan çalışmalarda FDG işaretli lökositlerin yararlı bir enfeksiyon görüntüleme ajanı olduğu ortaya konulmuş olsa da uygulama ile ilgili bazı güçlükler vardır. FDG'nin 110 dakikalık yarı ömrü, 2-3 saatlik işaretleme prosedürü için çok elverişli değildir. Yine kısa yarı ömür nedeni ile bazı durumlarda çok yararlı olan 24. saat görüntüleme yapılamaz. Ayrıca lökositlerin FDG ile işaretlenme etkinliği, In-111 ile olana göre daha düşük ve değişkendir. FDG işaretli lökositlerin stabiliteside In-111 işaretli lökositlere göre düşüktür. ${ }^{[20]}$

\section{Galyum-68 sitrat PET}

Pozitron yayan ve PET radyofarmasötiği olan Ga-68 ile, yaklaşık 50 yıldır enfeksiyon görüntülemede kullanılan SPECT radyafarmasötiği olan Ga-67'nin enfeksiyonda tutulum mekanizmaları aynıdır. İnflamasyon, travma ve tümör gibi yanlış pozitiflikler Ga-68 için de geçerlidir. PET radyofarmasötiği olduğundan görüntü kalitesi Ga-67'den üstündür. Ga-68'in yarı ömrünün kısa olması nedeni ile (68 dakika) uzun yarı ömürlü Ga-67'ye göre (78 saat) çok daha kısa sürede görüntüleme sağlar. Ancak bu durum geç görüntülerin alınması açısından dezavantaj oluşturur. Ga-68'ile Ga-67'nin düşük görüntü kalitesi, görüntülenme süresi gibi dezavantajları aşılmış olsa da halen özgüllüğünün düşük olması problem oluşturmaktadır. Bu nedenle Ga-68'i sideroforlar ve antimikrobiyal peptidlerle kompleks haline getirerek daha spesifik radyofarmasötikler geliştirebilmek için çalışmalar devam etmektedir. ${ }^{[3,21]}$

\section{I-124 Fialuridin PET}

Bakteriyel timidin kinazın spesifik bir substratı olan Fialuridin, I-124 ile işaretlenerek canlı bakterilerin tespitinde bir radyofarmasötik olarak kullanılmak istenmiştir. Enfeksiyona spesifik olması beklenen bu radyofarmasötik kullanılarak, kas-iskelet sistemi enfeksiyonu olan sekiz hastayla yapılan bir pilot çalışmadan olumlu sonuçlar alınmış olsa da, daha sonra yapılan çalışmalar hayal kırıklığı yaratmıştır. ${ }^{[22,23]}$

\section{ENDIKASYONLAR}

Hiçbir görüntüleme yöntemi iskelet sisteminin tamamında eşit derecede etkin değildir. En uygun yöntemin seçimi, enfeksiyondan şüphelenilen alanın yerine ve hastanın klinik durumuna bağlıdır. Kas-iskelet sistemi enfeksiyonlarını periferik osteomiyelit, spondilodiskit, protez enfeksiyonları ve diyabetik ayak olarak kategorilere ayırmak yararlı olacaktır.

\section{Periferik Osteomiyelit}

Her ne kadar periferik kemik enfeksiyonları osteit (kemik ve çevresindeki yumuşak dokuların egzojen bakteriyel enfeksiyonu) ve osteomiyeliti (kemik iliğinin çoğunlukla hematolojik yayılımla gelişen ve kortikal kemiği de etkileyen enfeksiyonu) içerse de literatürde birbirlerinin yerine kullanılmakta, teşhiste benzer yöntemler kullanılmaktadır.[24] Osteomiyelit çoğunlukla travma, cerrahi ve özellikle protez implantları sonrası gelişir ve egzojen orijinlidir. Ancak immunosupresyon gibi durumlarda hematojen yayılımla da oluşabilir. Periferik kemik enfeksiyonları aksiyel kemik enfeksiyonlarından (özellikle vertebra) etyoloji ve klinik davranış olarak farklılıklar gösterdiğinden tanı algoritması da farklııı göstermektedir.

Periferik kemik enfeksiyonu şüphesinde ilk basamakta klinik muayene, laboratuvar testleri (yükselme veya düşme eğilimini takip için) direkt grafi ve uygun hastalarda 'probe to bone' testi (kemik sondajı) yapılmalıdır. Şüphenin devam etmesi halinde görüntü kılavuzlu kemik biyopsisi ve ileri tanısal görüntüleme testleri yapılmalıdır. Illeri tanısal görüntüleme olarak radyolojik (MRG) ve/veya nükleer tıp teknikleri kullanılır.

ÜFKs, enfeksiyon ihtimali düşük olan hastalarda yüksek duyarlılığı, ulaşılabilirliği ve düşük maliyeti ile enfeksiyonu dışlamak için uygun bir testtir. ${ }^{[24]}$ Pozitif olması durumunda özgüllüğü düşük olduğundan başka görüntüleme yöntemleri ile doğrulanmalıdır (ILs, AMAs veya PET).

Enfeksiyon ihtimali yüksek olan hastalarda ise ilk görüntüleme testi olarak İLs tercih edilir. İLs'de radyoaktivite bozunumu için düzeltilmiş görüntüleme süreleri 
ve radyoaktivite bozunumuna göre düzenlenmiş belirli sayımlarla yapılan 30 . dakika, $2-4$. saat ve $20-24$. saat görüntülemeleri içeren protokolün kullanılması ile mükemmel bir teşhis doğruluğu sağlanır. Görsel değerlendirme ile enfeksiyon düşünülen alanda zamanla radyoaktivite tutulumunda artış olması enfeksiyon olduğunu, azalma olması enfeksiyon olmadığını gösterir. Ayrıca radyoaktivite tutulumu olan alanın boyutunda artış veya şeklinde değişme de (fistül işareti olabilir) enfeksiyon olarak değerlendirilir. Görsel olarak herhangi bir artış veya azalma tespit edilemiyorsa semikantitatif değerlendirme ile enfeksiyon kararı verilebilir. Semikantitatif değerlendirmede osteomiyelit ve enfekte osteosentez için en iyi referans doku, kontralateral kemik iliği olarak tespit edilmiştir. ${ }^{[10]}$

İLs ile enfeksiyon mevcudiyetine karar verilemeyen olgularda Kìs'nin eklenmesi özgüllüğü artırır. İşaretli lökositler hem enfeksiyon, hem de kemik iliğinde tutulum gösterdiğinden sadece kemik iliğinde tutulum gösteren radyokolloidler bir ayraç olarak kullanılırlar. İşaretli lökositlerin akümüle olduğu alanda radyokolloid tutulumu olmaması enfeksiyonu gösterir. İLs'ne alternatif olarak AMAs kullanılabilir. Periferik osteomiyelit tanısında her iki test benzer yüksek tanısal doğruluk derecesine sahiptir. ${ }^{[10]}$

SPECT/BT, patofizyolojinin anatomi ile birleştirilmesinin sinerjistik etkisi ile birçok sintigrafik görüntülemede katkı sağladığı gibi osteomiyelit tanısında da doğruluğu artırır. İLs'de planar görüntüler enfeksiyonu steril enflamasyondan ayırt etmeye izin verse de SPECT/ BT kemik enfeksiyonunun derecesinin tespit etmede ve kemiğe komşu yumuşak doku enfeksiyonunun kemik enfeksiyonundan ayırt edilmesinde yararlıdır. ${ }^{[25]}$ Bu nedenle planar görüntüler pozitif olduğunda cihaz mevcutsa SPECT/BT önerilir. SPECT/BT için 3-4. saat veya $20-24$. saat seçilebileceği gibi $6-8$. saatte tek bir görüntüleme zamanı da tercih edilebilir.

FDG PET kırık, cerrahi girişim ve ortopedik cihaz olmayan periferik kemik enfeksiyonlarında yüksek tanısal doğruluğa sahiptir. FDG hem enflamatuvar hem de enfeksiyöz lezyonlar tarafından tutulduğu için yakın zamanda kırı//cerrahi veya ortopedik cihaz varlığında tanısal değeri düşer. Kırıktan sonra ve ortopedik cihazı bulunan hastalarda ise ILs tercih edilen radyonüklid görüntüleme tekniğidir. FDG PET'in enfeksiyon tanısında kullanmak için net yorumlama kriterleri olmayıp tanı genellikle subjektif kriterlere ve tecrübeye dayanır. Akut osteomiyelit tanısında FDG PET'in rolü yeterli sayıda çalışma olmadığından hala tam olarak bilinmemektedir. Ancak diğer görüntüleme yöntemlerinin yeterli tanısal başarıya ulaşamadığı kronik osteomiyelitlerde (semptomları altı haftadan daha uzun süren, nüks şüphesi olan) FDG PET'in başarısı yapılan çalışmalarla gösterilmiştir. ${ }^{[26]}$ Ancak yine de FDG PET'in periferik kemik enfeksiyonları tanısında ILs'den üstün olduğunu söylemek için yapılan çalışma sayısı yeterli değildir. Halen her iki tetkik de kırık ve ortopedik cihazı olmayan hastalarda aynı tanısal hassasiyetle kullanılabilir. ${ }^{[27]}$ Enfeksiyonun hematojen yayılımı konusunda şüphe olması durumunda FDG PET ilk tercih edilen yöntemdir. ${ }^{[24]}$ Özellikle çocuklarda dissemine osteomiyelit olabileceğinden her ne kadar çocuk doktorları radyasyon maruziyeti nedeni ile tüm vücut MRG'yi tercih etseler de FDG PET/BT'de akılda tutulmalıdır. ${ }^{[28]}$ Günümüzde artık tek başına $P E T$ modası geçmiş bir yöntem olup PET/BT kullanılmaktadır.

Govaert ve ark. 2017 yılında periferal posttravmatik osteomiyelitin tanısında görüntüleme modalitelerinin doğruluğunu inceleyen bir derleme yayımlamışlardır. İLs (veya AMAs)'nin duyarlıığını \%50-100, özgüllüğünü \%40-97 olarak bulurken SPECT/BT'nin eklenmesi ile duyarlılığın \%100'e özgüllüğün \%89-97'ye yükseldiğini; PET/BT ile duyarlılığın \%86-94, özgüllüğün \%76100 olduğunu bildirdiler. ${ }^{[29]}$ AMAs özellikle kronik osteomiyelitin tespitinde yüksek özgüllükle kullanılabilir. Savaş ilişkili periferal kas-iskelet sistemi enfeksiyonlarında Tc-99 m sulesomab ile yapılan AMAs'nin enfeksiyonu göstermede \%72 duyarlılığa, \%88 özgüllüğe sahip olduğu gösterilmiştir. ${ }^{[30]}$

Periferik kemik enfeksiyonu tanısında doğru algoritmayı seçmede kanıta dayalı kılavuz eksikliğini gidermek için 2019 yılında EANM (Avrupa Nükleer Tıp Derneği), EBJIS (Avrupa Kemik ve Eklem Enfeksiyon Derneği) ve ESR (Avrupa Radyoloji Derneği) tarafından (ESCMID/Avrupa Mikrobiyoloji ve Enfeksiyon Hastalıkları Derneği onaylı) yetişkinlerde periferik kemik enfeksiyonu tanısı için konsensus belgesi niteliğinde bir makale yayımlanmıştır. Dört derneğin delegelerinin literatür taramaları neticesinde ortak görüşle bir tanı akış şeması geliştirilmiştir. ${ }^{[24]}$

Periferik osteomiyelit tanısında radyolojik ve radyonüklid görüntüleme yöntemlerini karşılaştıran fazla sayıda çalışma yoktur. Nonkontrast MRG periferik osteomiyelitin tanısında yüksek duyarlılık (\%88-98), özgüllüğe (\%70-96) ve tanısal doğruluğa (\%81-86) sahip olması nedeni ile ilk tercih olabilir. ${ }^{[31]}$ Kontrastlı MRG tanısal doğruluğu artırmamaktadır. MRG'de şüpheli sonuç varsa veya MRG çekilemiyorsa nükleer tıp yöntemleri kullanılabilir. Ancak bir merkez nükleer tıp yöntemlerinde çok tecrübeli ise ilk olarak bu yöntemleri kullanabilir. ${ }^{[24]}$ Kullanılacak nükleer tıp yöntemini seçerken enfeksiyon olasılığının düşük veya yüksek olması, yakın zamanda ameliyat veya kırık öyküsünün olup olmaması, ortopedik cihazların bulunup bulunmaması dikkate alınarak aşağıdaki akış diyagramına göre karar verilebilir (Şekil 2). 


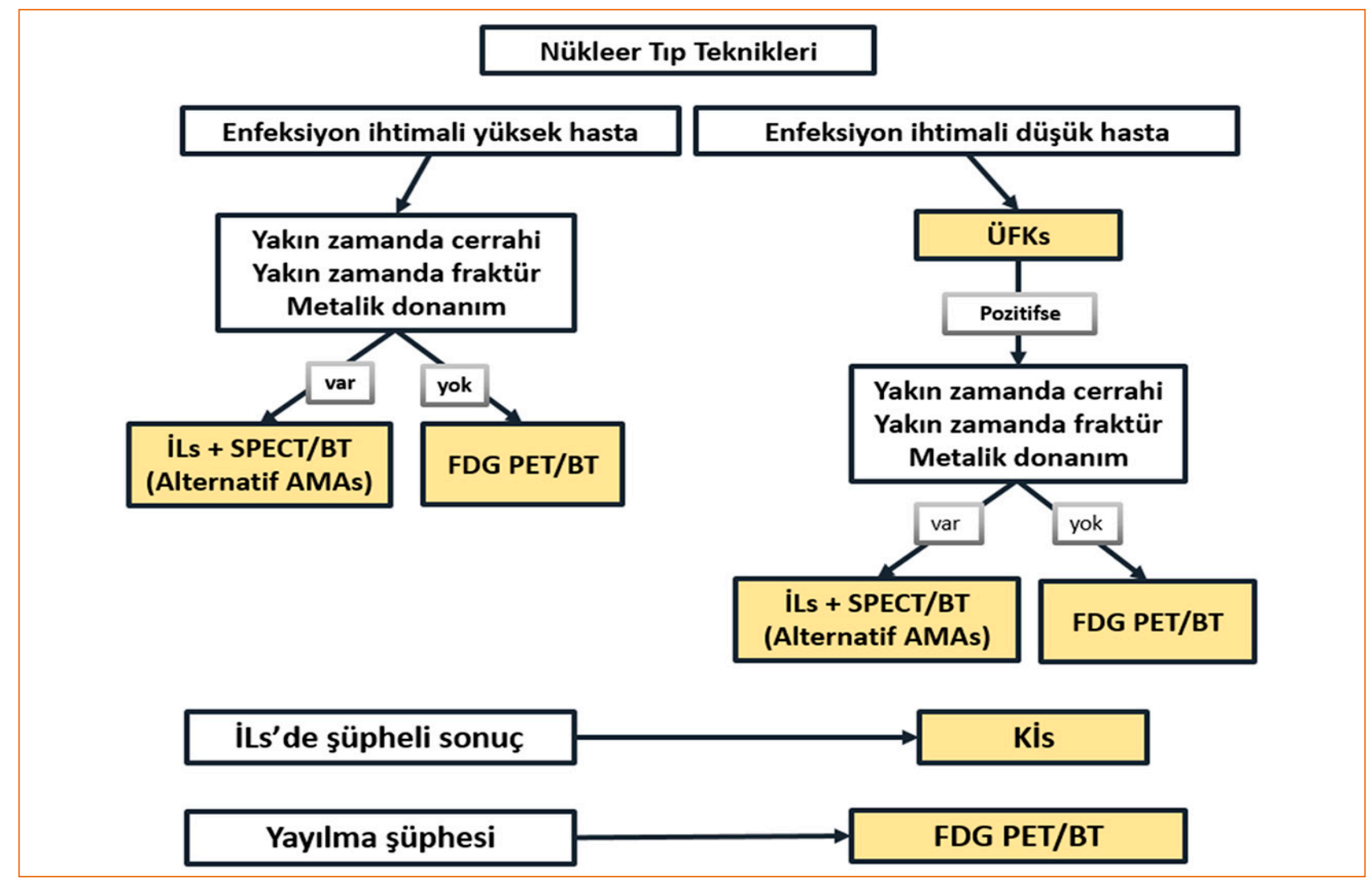

Şekil 2. Periferik osteomiyelit tanısında kullanılacak nükleer tıp teknikleri için önerilen akış şeması. ${ }^{\text {[24] }}$ (Springer yayınevinin izniyle; bu şekil CC BY 4.0 lisansı ile lisanslanmıştır ve Türkçe'ye çevrilerek adapte edilmiştir.)

\section{Spondilodiskit}

Vertebral enfeksiyonlar; spondiliti (vertebranın enfeksiyonu), diskiti (intervertebral diskin enfeksiyonu) ve spondilodiskiti (ardışık iki vertebra korpusunun ve aralarındaki intervertebral diskin enfeksiyonu) içerir. Primer spondilodiskitte patojenler direkt hematojen yolla veya nadir de olsa komşu yumuşak dokudan (enfekte aort grefti veya retrofarengeal abse gibi) vertebraya ulaşırlar. Endokardit, septik artrit ve idrar yolu enfeksiyonu gibi predispozan durumlar olabilir. Sekonder spondilodiskit ise cerrahi veya girişimsel işlemler sırasında mikroorganizmaların kontaminasyonu ile gelişir. Spondilodiskitin en sık görüldüğü bölge lomber vertebralardır (\%45). Daha sonra torakal (\%35) ve servikal vertebralar (\%20) gelir. Spinal enfeksiyonlar vertebra korpusunun damardan zengin olan anterolateral kesiminde end plate'e yakın başlar ve bu sayede komşu intervertebral diske ve vertebraya kolaylıkla yayılabilir. ${ }^{[1]}$ Sıklıkla yumuşak doku abseleri eşlik eder. Posterior elemanlarda tutulum \%20 olarak bildirilmiştir. ${ }^{[3]}$ Spondilodiskit çoğunlukla piyojenik orjinli olup \%60 etken Staphilococcus aureus'tur. Mycobacterium tuberculosis, Brusella, mantar ve parazitler daha az görülen piyojenik olmayan ajanlardır. Piyojenik spondilodiskitlerin \%95'i vertebra korpusunda yerleşmekte olup posterior elemanlarda yerleşimi nadirdir. Posterior elemanların tutulumu genellikle tüberküloz ve fungal enfeksiyonlarda gelişir. Çocuklarda enfeksiyon arteriyel anastomoz yapısından dolayı genellikle diskte başlar ve diskle sınırlıdır. ${ }^{[32]}$

Spondilodiskit tanısı klinik, laboratuvar ve görüntüleme bulgularına dayanır. Ayırıcı tanıda, osteoporotik ve patolojik kırık, eroziv osteokondroz, ankilozan spondiloartrit, Scheuermann hastalığı, kemik metastazı ve ameliyat sonrası değişiklikler yer alır. Son yıllarda spondilodiskit tanısında hassasiyet artmış olsa da yine de zordur; tanı sıklıkla atlanır veya gecikir. Spondilodiskit, uzun süreli antibiyotik tedavisi ve hastalık kontrol altına alınamazsa cerrahi gerektirir. Tedavi edilmeyen spondilodiskitler korpusta çökme gibi deformitelere ve nörolojik defisitlere neden olabilir. Uygun tedavi yönetiminin sağlanabilmesi için spondilodiskitin erken tanısı, enfeksiyonun lokalizasyonu, yaygınlığı ve şiddeti, komplikasyonların varlığının doğru şekilde tespiti esastır. ${ }^{[1]}$ 
MRG spinal cerrahi geçirmemiş hastalarda vertebral osteomiyelitin tanısında \%97 duyarlılık, \%93 özgüllük ve \%94 doğrulukla tercih edilecek görüntüleme yöntemi olarak önerilmektedir. ${ }^{[33]}$ Yumuşak doku ve kemik iliği patolojilerinde çok duyarlı olması, multiplanar görüntüleme kapasitesi, yüksek kontrast rezolüsyonu, iyonizan radyasyon içermemesi MRG'yi spondilodiskit tanısında en uygun yöntem yapar. Ancak tedavi takibinde; klinik iyileşmeye rağmen MRG bulguları kötüleşebileceğinden uygun değildir. MRG'nin başlıca yararı enfeksiyonun erken evrelerinde diğer radyolojik yöntemler henüz normalken bulgu vermesidir. Hastaların yarısında ilk iki haftada MRG ile enfeksiyon tespit edilebilmektedir.

BT, kemik tutulumunun derecesini tanımlamada MRG'yi tamamlayıcı olabilir. Ancak günümüzde BT'nin kullanım alanı daha çok perkütan iğne biyopsisi ve perkütan abse drenajıdır. Ayrıca ameliyat sonrası erken dönemde implant yerleşimini ve pozisyonunu değerlendirmede çok iyidir. MRG kontrendikeyse, mevcut değilse veya sonuçlar şüpheli ise BT spondilodiskit tanısında kullanılabilir. ${ }^{[34]}$

Kemik sintigrafisi kolay ulaşılabilirliği nedeni ile tarama testi olarak kullanılıyor olsa da yanlış negatiflikleri çoktur. Enfeksiyon iyileştikten sonra bile remodeling uzun süre devam ettiğinden kemik sintigrafisi pozitif olmaya devam eder. Spondilodiskite sıklıkla eşlik eden yumuşak doku enfeksiyonlarının tanısında kullanışlı değildir.

Ga-67 sitrat sintigrafisi spondilodiskit şüphesi olan hastalarda yararlı bilgiler verir. Spondilodiskit tanısında kemik sintigrafisi ve Ga-67 sitrat sintigrafisinin duyarlılıkları sırasıyla $\% 81,4$ ve $\% 86,3$; özgüllükleri sırasıyla $\% 40,7$ ve $\% 35,8$ olarak bildirilmiştir. ${ }^{[35]}$ Kemik sintigrafisi ile Ga-67 sitrat sintigrafisinin kombine edilmesi ile tanısal doğruluk arttırılabilir ancak spesifite artmaz. Ga-67 sitrat sintigrafisinde tutulum kemik sintigrafisinden daha yüksek ise enfeksiyon, kemik sintigrafisinde daha yüksek tutulum izleniyorsa dejeneratif patolojiler olarak değerlendirilir. Kemik/Ga-67 sintigrafisinin genel doğruluğu yaklaşık \%65-80'dir. ${ }^{[36]}$

İLs, iskelet sisteminin diğer kesimlerinin aksine vertebral osteomiyelitlerde yararlı değildir. Vakaların yarısından fazlasında enfeksiyon alanı soğuk odak şeklinde görülür. Bu görünüm enfeksiyona özgü olmayıp tedavi olmuş spondilodiskit alanları, kompresyon kırı̆ıı, infarktüs, tümörler ve Paget hastalığı da hipoaktif görünüme neden olabilir. Ayrıca bu bulgu sadece in vitro işaretlenmiş İLs'de değil, in vivo işaretli lökosit sintigrafilerinde de gözlenmiştir.

In-111 biotin sintigrafisi kemik iliği tutulumunun olmaması veya çok az olması, Ga-67'den daha düşük radyasyon maruziyeti olması, aynı gün görüntüleme yapılabilmesi, antibiyotik tedavisinden etkilenmemesi gibi avantajları ile spinal enfeksiyonlarda yararlı bir görüntüleme yöntemi olmakla birlikte maalesef dünya çapında sadece birkaç merkezde temin edilebilmektedir. Lazzeri ve ark., yaptıkları ileriye dönük bir çalışmada duyarlıı̆̆ı \%93, özgüllüğ̈̈ \%90 bulmuşlardır. ${ }^{[37]}$

FDG PET, spondilodiskitte çok kapsamlı araştııılmıştır. PET ve PET/BT spondilodiskit tanısında oldukça yüksek duyarlılık, ancak nispeten düşük spesifite göstermiştir (Şekil 3). Spondilodiskit tanısında kullanılan diğer radyonüklid görüntüleme yöntemleri olan kemik sintigrafisi ve Ga-67 sitrat sintigrafisi ile karşılaştırıldığında en iyi tanısal doğruluğu \%89 duyarlılık ve \%88 özgüllük ile PET/BT'nin gösterdiği tespit edilmiştir. ${ }^{[36]}$ Enfeksiyonu tümörden güvenli bir şekilde ayıramaması dezavantajıdır. Dejeneratif değişikliklerde FDG tutulumu genellikle düşük olsa da, vertebranın dejeneratif hastalıklarında belirgin fokal tutulum meydana gelir.

Kim ve ark. tarafindan yapılan ve 2019 yılında yayımlanan meta-analizde spondilodiskit tanısında FDG $P E T$ ve MRG'nin tanısal doğruluğu karşılaştırılmıştır. Bu meta-analiz sonuçlarına göre FDG PET spondilodiskit tanısında MRG'den daha iyi tanısal doğruluğa sahiptir. FDG PET için birleştirilmiş duyarlılık ve özgüllük \%95 ve \%88; MRG için bu değerler $\% 85$ ve $\% 66$ olarak bildirildi. ${ }^{[38]}$

Hungenbach ve ark., spondilodiskitte FDG tutulum paternlerinin spondilodiskiti tahmin etmede veya ekarte etmede yardımcı olacağını belirtmişlerdir. Hastalığın şiddetine göre 5 farklı FDG tutulum paterni tanımlayarak bu paternlere göre diskit/spondilodiskit kararı verdikleri çalışmalarında duyarlılığı \%86, özgüllüğü \%95 olarak tespit etmişlerdir. Bulgular aşağıdaki şekilde skorlanmıştır ${ }^{[39]}$ :

Skor 0: Normal bulgular ve fizyolojik FDG dağılımı.

Skor 1: Intervertebral veya paravertebral bölgede fizyolojik kemik iliği tutulumunun hafifçe üzerinde artmış tutulum.

Skor 2: İntervertebral alanda lineer veya diskoid paternde fizyolojik kemik iliği tutulumunun üzerinde belirgin artmış tutulum.

Skor 3: Intervertebral alanda lineer veya diskoid paternde fizyolojik kemik iliği tutulumunun üzerinde belirgin artmış tutulum ve diske komşu ardışık vertebraların birinde veya her ikisinde end-plate tutulumu.

Skor 4: İntervertebral alanda lineer veya diskoid paternde fizyolojik kemik iliği tutulumunun üzerinde belirgin artmış tutulum ve diske komşu ardışık vertebraların birinde veya her ikisinde end-plate tutulumu + çevreleyen yumuşak doku absesi. 

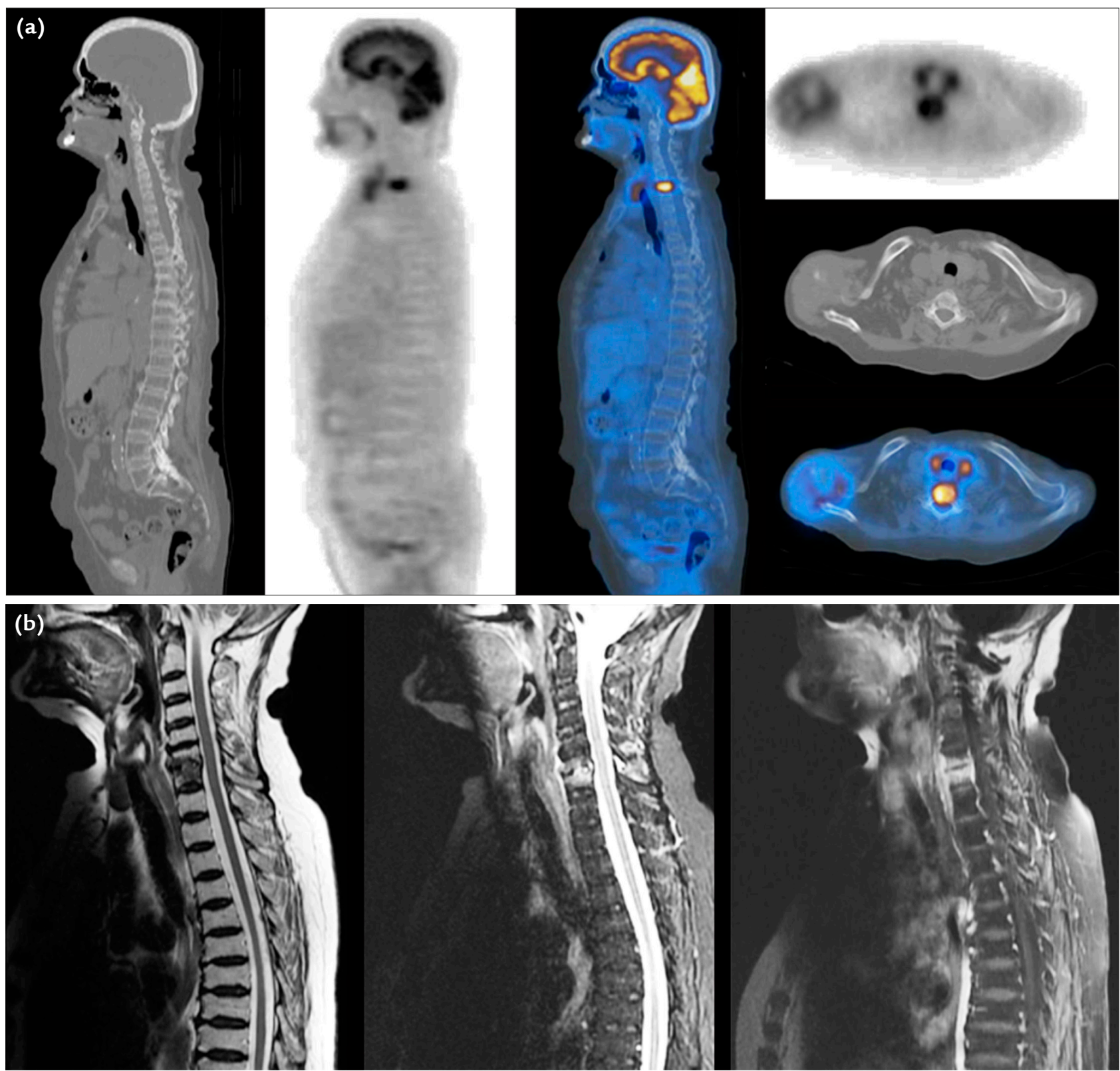

Şekil 3. a, b. Seksen yaşında myelodisplastik sendrom tanılı kadın hastada kan kültüründe metisiline duyarlı Staphylococcus aureus (MSSA) üremesi üzerine enfeksiyon odağı araştırılması amacıyla FDG PET-BT çalışması yapılmış (a). C6-C7 vertabra düzeyinde intervertebral disk ve ardışık vertabra korpusu end-plate'lerinde spondilodiskiti düşündüren, enfeksiyon odağı açısından anlamlı derecede artmış FDG tutulumu izlenmekte (SUVmaks: 11,7). MRG'de ise C6-C7 vertabra seviyesinde osteomiyeliti destekleyen T2A sinyal artışı, diske komşu vertebral end-plate'lerde C7 vertabra korpusunun inferior end-plate'ine kadar uzanan T1A ve T2A'da hipointens sinyal değişiklikleri, diskte ve diske komşu vertabralarda ödem kontrastlanma, anterior longitudinal ligamenti eleve etmiş paravertebral enflamatuvar doku izlenmekte (b).

Skor 0 ve 1 normal veya nonspesifik (spondilodiskit değil), Skor 2 diskit, Skor 3 ve 4 spondilodiskit olarak sınıflandırıldı. ${ }^{[39]}$

Fahnert ve ark., yaptıkları ileriye dönük çalışmada yetersiz MRG sonuçları olan 30 spondilodiskit şüpheli hastaya PET/MRG uyguladılar. FDG PET eklenmesi ile
MRG'nin duyarlılığının \%50'den \%100'e, özgüllüğünü \%71'den \%88'e, PPV'in \%54'ten \%86'ya, NPV'in \%67'den \%100'e yükseldiğini gösterdiler. Ayrıca bu çaıışmada etkilenen disk/referans disk SUVmax oranları 2,1 alındığında spondilodiskiti \%92 duyarlılık ve \%88 özgüllük (ROC: 0,95) ile gösterdiğini tespit ettiler. ${ }^{[40]}$ 
Tüberküloz spondilodiskitin tedavisi piyojenik spondilodiskitten farklı olduğu için FDG PET/BT ile iki antitenin ayırt edilip edilemeyeceği ile ilgili özellikle geç görüntüleri içeren çalışmalar yapılmış, ancak bu iki tip enfeksiyonun FDG PET/BT ile ayrımı gösterilememiştir.

Vertebral implantlarda enfeksiyon tanısının bazı güçlükleri vardır. Yabancı cisim varlığından dolayı immun cevap tetiklenerek enfeksiyon olmasa bile implant çevresinde FDG tutulumu gözlenebilir. Winter ve ark., ameliyat sonrası vertebral enfeksiyonun tanısında FDG PET'in özgüllüğünün implant olanlarda \%92'den \%65'e düş̧ügüünü göstermişlerdir. ${ }^{[41]}$ Daha sonraki yıllarda PET yerine PET/BT'nin kullanıldığı çalışmalarda daha iyi sonuçlar elde edilmiştir. Ancak metalik cihazların yüksek dansitesi aşırı atenüasyon düzeltmesine neden olacağından görüntüler atenüasyon düzeltmesi yapılmamış görüntülerden de değerlendirilmelidir. Cerrahi sonrası non-spesifik FDG tutulumunun ortadan kalkması için en az dört ay geçmelidir.

Inanami ve ark. vertebral enstrümantasyonu bulunan hastalarda cerrahi alan enfeksiyonunun tanısında FDG PET/BT'nin rolünü araştırdıkları çalışmalarında sekiz enfeksiyon şüphesi olan hasta ve altı kontrol hastasını değerlendirdiler. Sonuçta enfeksiyon tespit edilen altı hastanın tamamının FDG PET/BT'de görsel değerlendirme ile pozitif, enfeksiyon tespit edilmeyen hastaların tamamının da negatif olduğunu, böylece FDG PET/BT'nin doğruluğunu \%100 bulduklarını bildirdiler. ${ }^{[42]} \mathrm{PET} / \mathrm{BT}$ 'nin en büyük yararlarından biri de enfekte implantın seçici olarak çıkarılabilmesi ve enfekte olmayan implantların da korunabilmesi için çıkarılması gereken implantın kararının verilmesindeki katkısıdır. Yapılan çalışma ve hasta sayıları kısıtlı olsa da cerrahi sonrası spinal enfeksiyonların tespitinde (cerrahi enstrüman olsun veya olmasın) FDG PET/ BT diğer görüntüleme yöntemlerinden daha iyi tanısal doğruluğa sahiptir. ${ }^{[34]}$

MRG'nin aksine FDG PET'in tedavi takibinde de kullanılabileceği gösterilmiştir. FDG PET/BT ile tanı konulmuş spondilodiskit tanılı hastalarda antibiyotik tedavisine yanıtı değerlendirmek için ikinci bir PET/ BT yapılabilir. ${ }^{[34]}$ Riccio ve ark., bazal PET/BT ile spinal enfeksiyonu gösterilen hastalarda ikinci PET/BT ile tedavi yanıtını değerlendirmek için bazı yorumlama kriterleri önerdiler. Buna göre kemik veya yumuşak dokuda FDG tutulumu, devam eden enfeksiyonu gösterirken; sadece diskin konturları ile sınırlı bir FDG tutulumu muhtemelen mekanik olarak tetiklenen enflamasyonu temsil eder ve enfeksiyon olarak değerlendirilmemelidir. Tedavi yanıtının değerlendirilmesinde FDG tutulum paterninin kullanıldığı bu yöntemle PET/ BT, tedavi yönetiminde geçerli bir yöntem olarak görünmektedir. ${ }^{[43]}$
Spondilodiskitte radyolojik ve nükleer tıp tekniklerinin uygulanması dünya çapında çok farklılıklar göstermekte ve genellikle lokal tecrübelere dayanmaktadır. Spondilodiskitte tanısal yaklaşımda homojeniteyi ve standardizasyonu sağlayarak tanı doğruluğunu artırmak amacıyla 2019 yilında EANM, ESCMID ve ESNR'in (Avrupa Nöroradyoloji Derneği) onayladığı, bir tanı akış diyagramı da içeren, uluslararası ve multidisipliner bir tedavi rehberi (guideline) yayımlanmıştır. ${ }^{[34]} \mathrm{Bu}$ akış şemasında şüpheli spondilodiskit durumunda hematojen kökenli durumlarda MRG'nin, cerrahi sonrasında ise FDG PET/BT'nin baskın rolü vurgulanmaktadır (Şekil 4).

\section{Protez Enfeksiyonları}

Son yıllarda artan yaşam beklentisine paralel olarak eklem protezi ameliyatlarının sayısında da önemli artış olmuştur. Bu ameliyatlar hastanın ağrısını azaltan ve eklem fonksiyonunu artıran düşük maliyetli ve güvenli ameliyatlar olsa da; en sık olarak aseptik gevşeme, daha az sıklıkla dislokasyon, fraktür, heterotopik ossifikasyon ve nadiren de enfeksiyon gibi ciddi komplikasyonlar görülebilmektedir. Protez enfeksiyonu ilk cerrahiden sonra \%2-4 oranında gelişirken, revizyon ameliyatlarından sonra ise oran \%20'ye kadar yükselmektedir. ${ }^{[4]}$ Protez enfeksiyonları tekrarlayan cerrahi müdahaleler, uzun hastane yatış süreleri ve uzun süreli antibiyotik kullanımları ile önemli ekonomik yük getiren ciddi bir komplikasyondur. Bu nedenle eklem fonksiyonlarını korumak ve başarılı bir tedavi sağlamak için enfeksiyonun hızlı bir şekilde tanınması gerekmektedir. Aseptik gevşemede; protez bileşenlerine karşı immun yanıt neticesinde gelişen yoğun lökosit birikimi ile kıkırdak ve kemik harabiyeti olur. Protez enfeksiyonlarını aseptik gevşemeden ayırt etmek büyük önem taşımaktadır. Zira aseptik gevşemede tek basamaklı bir revizyon artroplastisi genellikle yeterli olurken, protez enfeksiyonunda birden fazla ameliyat ve antibiyoterapiyi kapsayan daha kompleks tedaviler gerekmektedir. Ancak protez enfeksiyonu ile aseptik gevşemeyi ayırt etmek, klinik bulguların ve histopatolojinin benzerliği nedeni ile çok güç olabilmektedir.

Protez enfeksiyonlarında genellikle patojenler, protezin etrafinda ince bir biyofilm tabakası oluşturarak bu tabakanın derininde konakçı bağışıklık sisteminden ve çoğu antibiyotikten korunurlar. Protez enfeksiyonlarının bu karakteristiği nedeni ile genellikle antibiyotiğe direnç gelişir; tanı ve tedavi protez çıkarılmadan oldukça güçtür. Biyofilm, işaretli lökositlerin enfeksiyon alanına geçişini azalttığından akümülasyon uzun süre alır. Bu nedenle İLs'de 24. saat görüntüleme şarttır. Bakteriler salgıladıkları kemotaktik faktörlerle protez çevresinde nötrofillerin toplanmasına neden olur. Protez enfeksiyonunda oluşan enflamasyon yoğun 


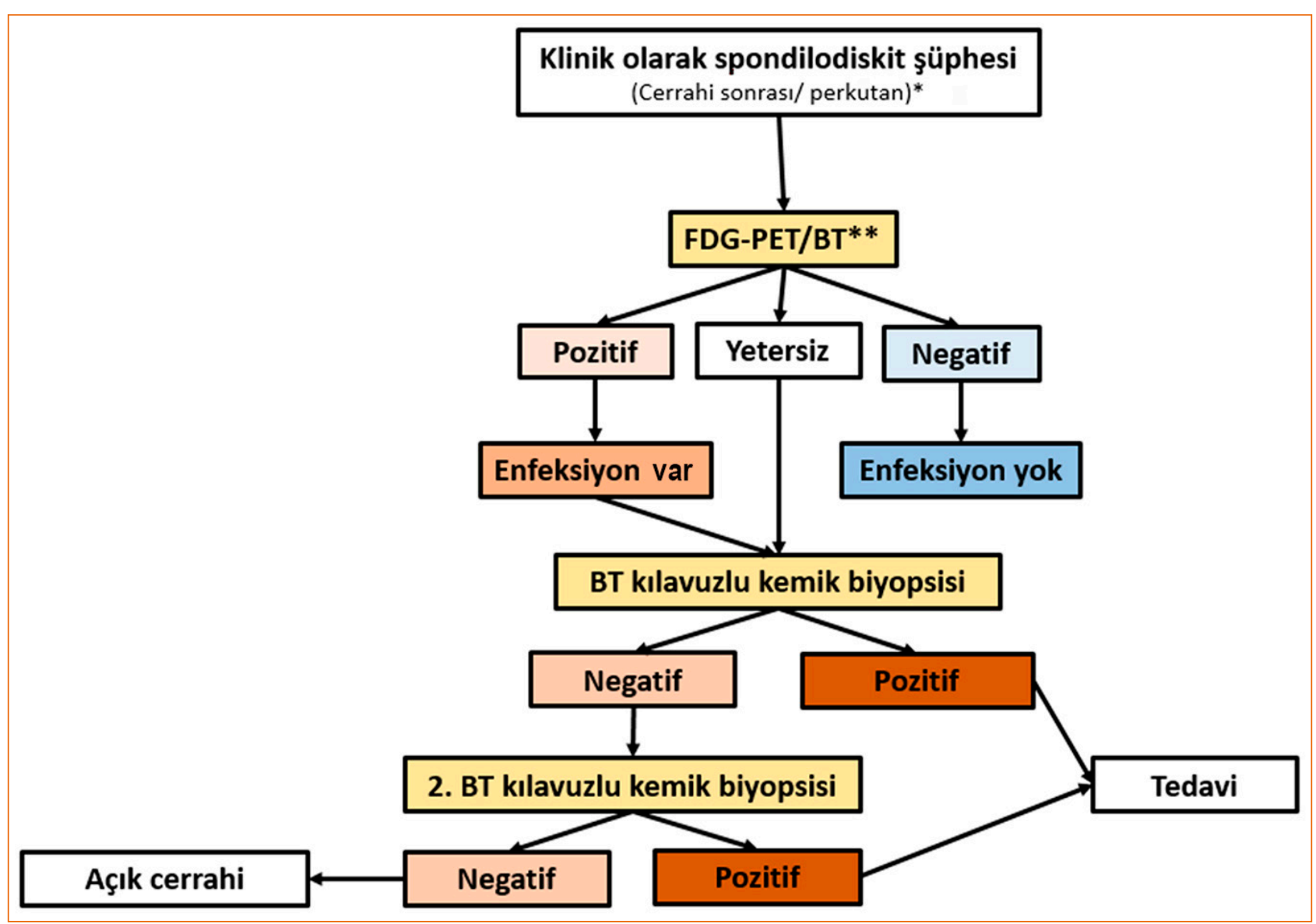

Şekil 4. Klinik olarak spondilodiskit şüphesi olduğunda tanı için takip edilecek akış şeması ( ${ }^{*}$ Hematojen orijinli spondilodiskit tanısında MRG tercih edilir. MRG'nin kontrendike olduğu veya yetersiz sonuç verdiği durumlarda FDG-PET/BT tercih edilir. * *FDG PET/BT kullanılamıyorsa kemik sintigrafisi/Ga-67 sintigrafisi kombinasyonu da [SPECT/BT ile] uygulanabilir). ${ }^{[34]}$

nötrofil içerirken aseptik gevşemede oluşan enflamasyonda nötrofiller nadirdir. İki klinik durumun patofizyolojisindeki bu fark çoğunlukla nötrofillerin işaretlendiği İLs ile ayırıcı tanıya imkan sağlar. Ancak kronik enfeksiyonlarda nötrofil yoğunluğu daha az olduğundan tanı güçleşmektedir.

Protez enfeksiyonları, ameliyattan sonra başlama zamanına göre erken (ilk üç ay), geç ( 3 ay -2 yıl) ve gecikmiş (2 yıldan sonra) olarak sınıflandırılabilir. Erken protez enfeksiyonunda en sık izole edilen patojen Staphylococcus aureus iken, geç enfeksiyonlarda ise koagülaz negatif stafilokoklar daha sıktır. Erken enfeksiyon, kızarıklık, şişlik, ısı artışı ve ateş gibi enfeksiyon bulguları ile kolayca tanınabilirken, geç enfeksiyonların tanısı sorun oluşturmaktadır. Semptomlar enfeksiyon tanısı için spesifik olmadığından, klinik öykü veya fizik muayene ile protez enfeksiyonunu aseptik gevşemeden ayırmak kolay değildir. Ağrılı protezi olan hastalarda yapılması gereken ilk testler eritrosit sedimentasyon hızı (ESR) ve serum C-reaktif protein (CRP) olmalıdır.
CRP $10 \mathrm{mg} / \mathrm{L}$, ESR $30 \mathrm{~mm} / \mathrm{sa}$ eşik değerleri ile protez enfeksiyonlarının tanısında etkin tanısal öntestlerdir. Ayrıca tedaviye yanıtın takibinde de kullanılırlar. Son yıllarda serum D-dimer'in de protez enfeksiyonu tanısında kullanılabilecek bir belirteç (marker) olduğu gösterilmiştir. ${ }^{[45]}$ Ancak bu testlerin negatif olması enfeksiyonu dışlamadığı gibi, en az birinin pozitif olması durumunda ek tanısal testlere ihtiyaç vardır. Eklem sıvı aspirasyonu bu aşamada önerilir. Sinoviyal sıvıda lökosit sayısının 3000 hücre/ $\mu$ l ve nötrofil oranlarının \%70'den fazla olması enfeksiyon için yükssek hassasiyet ve özgüllük göstermektedir. ${ }^{[46]}$ Sinoviyal SIVı aspirasyon kültürünün özgüllüğgü yüksek, duyarlılı̆ı ise daha düşüktür. Bu nedenle protez enfeksiyonunu dışlamaktan ziyade kanıtlamak için elverişlidir. Son on yılda protez enfeksiyonlarının tanısındaki güçlüklerin, sinoviyal sıvıdaki biyomarkırların ölçülmesiyle aşılabileceğini düşündüren çok sayıda umut verici çalışma yapılmıştır. Özellikle alfa defensin çok yüksek duyarlılık (\%95,5-100) ve özgüllük (\%95-100) göstermiştir. ${ }^{[46,47]}$ Diğer sinoviyal biyomarkır 


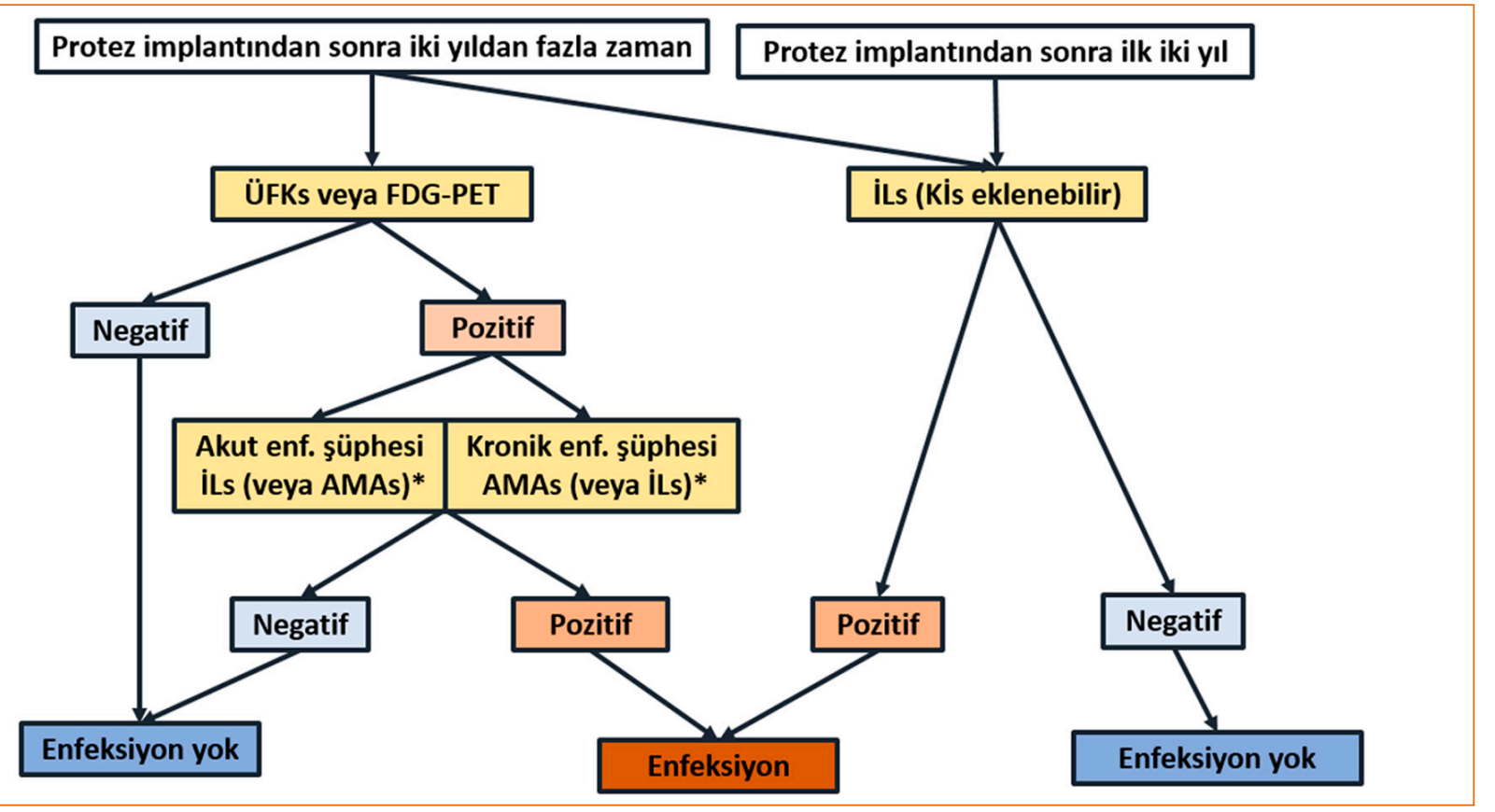

Şekil 5. Protez enfeksiyonu tanısında nükleer tıp teknikleri için tavsiye edilen algoritma. İki yıllık süre kalça ve omuz protezleri için geçerli olup diz protezleri için fizyolojik enflamasyon beş yıla kadar uzayabilir. Çimentolu protezlerde enflamasyon süresi çimentosuzlardan daha kısadır ( ${ }^{*}$ Bu görüntüleme yöntemleri için metodoloji son derece önemli olup EANM kılavuzunda yayımlanan radyoizotop bozunumuna göre düzenlenmiş sürelerde alınan üç zamanlı görüntüleme protokolü önerilir. Özgüllüğü daha da artırmak için Kìs eklenebilir). ${ }^{[46]}$ (Springer yayınevinin izniyle; bu şekil CC BY 4.0 lisansı ile lisanslanmıştır ve Türkçeye çevrilerek adapte edilmiştir.)

olan lökosit esteraz, interlökin 6, sinoviyal CRP ile ilgili de çalışmalar yapılmaktadır. Eklem sıvı aspirasyonu yapılamayan durumlarda operasyon öncesi tanıyı kesinleştirmek için doku biyopsisi yapılarak histolojik değerlendirme ve kültürler çalışılabilir. Görüntülemede yapılacak ilk tetkik, hem implantın hem de kemik dokunun değerlendirilebildiği direkt grafi olmalıdır. Ancak septik aseptik gevşeme ayrımı neredeyse imkânsızdır.

Protez enfeksiyonu tanısında kesin doğrulukta bir testin olmaması nedeni ile tıbbın diğer birçok alanında olduğu gibi (romatoid artrit, ankilozan spondilit vs.) tanı kriterleri geliştirerek tanıda standardizasyon sağlanmaya çalışılmıştır. 2011 yılında laboratuvar, kültür ve histopatolojik majör ve minör bulgularla tanı konulmaya çalışılan MSIS (Musculoskeletal Infection Society) kriterleri. ${ }^{[48]}$ yayımlanmıştır. MSIS kriterleri yeni kullanıma giren testlerin de eklenmesi ( $D$ dimer, alfa defensin ve lökosit esteraz), kriterlerin ameliyat öncesi ve ameliyat sırasında olarak ayrılması ve minör kriterlere skorlar getirilmesi ile 2018 yllında güncellenmiştir. ${ }^{[45]}$ Yeni geliş̧tirilen bu kriterler MSIS kriterlerine kıyasla $(\% 79,3)$ daha yüksek duyarlılığa $(\% 97,7)$ ve benzer özgüllüğe $(\% 99,5)$ sahiptir. Ancak bu kriterlerle de ameliyat sırasında tanı kriterleri dâhil edildiğinde bile tanı konulamayan gri bir alan kalmaktadır. Bu grup için de bir moleküler genetik yöntem olan 'yeni nesil sekanslama' önerilmiştir. ${ }^{[45]} \mathrm{Her}$ ne kadar tanımlanan kriterlere görüntüleme yöntemleri dâhil edilmemiş olsa da özellikle nükleer görüntüleme yöntemlerinin etkinliğini gösteren çok sayıda bilimsel çalışma vardır.

2019 yilında EANM, EBJIS ve ESR tarafindan (ESCMID onaylı); eklem protezi enfeksiyonlarının tanısında klinisyenlere en doğru tanısal stratejiyi seçmede yardımcı olmak için konsensus belgesi niteliğinde multi-disipliner bir rehber yayımlanmıştır. ${ }^{[46]}$ Bu rehberde ayrıca tanısal bir akış şeması geliştirilerek nükleer görüntüleme yöntemlerini de kapsayan bir algoritma sunulmuştur.

Bu kılavuza göre protez enfeksiyonu şüphesinde ilk yapılacak testler CRP, ESR, kan lökosit düzeyi, direkt grafi ve kan kültürünün ardından enfeksiyon şüphesi devam ediyorsa kemik veya yumuşak doku biyopsisi, ya da görüntüleme altında eklem sıvı aspirasyonu düşünülmelidir. Sinoviyal biyomarkerlar ve kültürler enfeksiyon için yüksek doğruluğa sahip olsa da kemik veya yumuşak doku tutulumunu, enfeksiyonun derecesini ve şiddetini değerlendirmek için ileri görüntüleme yöntemleri ile entegre edilmeleri gerekir. Bu yöntemler de ya MRG veya nükleer tıp teknikleri olmalıdır (Şekil 5). 
MRG'nin kullanımı geleneksel olarak özellikle metalik artefaktlar nedeni ile sınırlı kabul edilmiştir. Ancak son yıllarda protez bileşenlerinde ve MRG sekanslarında yaşanan teknolojik gelişmeler özellikle MRG'yi protez enfeksiyonları tanısında tamamen elverişli hale getirmiş̧ir. ${ }^{[46,49]}$

ÜFKs, protez enfeksiyonlarının tanısında enfeksiyon şüphesinin düşük olduğu grupta tarama testi olarak kullanılabilir. Negatif bir tarama enfeksiyon tanısını dışlar. Ancak pozitif bir tarama varlığında enfeksiyonu doğrulayacak başka tetkikler gerekir. Kanlanma, kan havuzu ve geç fazda tutulum olması protez enfeksiyonunu düşündürürken, kanlanma ve kan havuzunda tutulum olmayıp sadece geç fazda tutulum olması aseptik gevşemeyi desteklemektedir. Kalça protezlerinde iki yıl, diz protezlerinde beş yıl remodeling devam edeceğinden ÜFKs pozitif olabilir. Ayrıca kalça protezlerinde radyoaktivite tutulum paterni aseptik gevşemeyi protez enfeksiyonundan ayırmada yardımcı olabilir. Femoral komponent gevşemesinde protez distal ucunda belirgin artmış radyoaktivite tutulumu ve periprostetik tutulum gözlenir; ayrıca trokanter minörde artmış tutulum da destekleyici bulgudur. Asetabular komponent gevşemesinde asetabular çatı ile kemik aralığında belirgin artmış radyoaktivite tutulumu vardır. Enfeksiyonda ise protez yüzeyinde kan havuzu fazında ve geç görüntülerde belirgin artmış tutulum gözlenir. ${ }^{[50]}$

İLs, ÜFKs pozitif olan hastalarda tanıyı doğrulamak için ilk tercih edilen görüntüleme yöntemidir. Bu algoritmanın kullanılması ile kalça protezi enfeksiyonlarının tanısında \%80 duyarlılık, \%99,5 özgüllük elde edildiği bildirilmiştir. ${ }^{[51]}$

İLs görüntüleme protokolünün 2018 EANM kılavuzunda da tanımlandığı gibi ${ }^{[14]}$ üç zamanlı ve radyoaktif bozunum dikkate alınarak belirlenmiş sürelerde elde edilmesinin protez enfeksiyonlarının tanısında da doğruluğu artırdığı gösterilmiştir. Semi-kantitatif değerlendirme, görsel değerlendirme ile tanı konulamayan hastalarda yardımcı olmaktadır. Protez enfeksiyonlarında semi-kantitatif değerlendirmede en iyi referansın kontralateral doku olduğu saptanmıştır. ${ }^{[10,52]}$

Eklem protezlerinde normal kemik iliği yapısı bozularak protez çevresinde hematopoetik aktif kemik iliği gelişir. İLs'de tutulumun kemik iliğinden mi yoksa enfeksiyondan mı kaynaklandığı üç zamanlı görüntüleme ve semi-kantitatif değerlendirmeye rağmen yapılamıyorsa Kís yararlı olacaktır. ${ }^{[46]} \mathrm{Her}$ iki radyofarmasötik benzer dağılım gösteriyorsa tutulumun kemik iliği aktivitesine bağlı geliştiği düşünülür. İLs'de tutulum olan alanda Kis'de aktivite olmaması ise enfeksiyonu gösterir. İLs/Kís kombinasyonunun doğruluğu hem diz hem de kalça ekleminde \%83-98 aralığında bildirilmiştir. Günümüzde standartlaştırılmış görüntüleme ve yorumlama kriterlerinin kullanılması giderek yaygınlaştığından İLs'nin tanısal doğruluğu giderek artmakta, Kìs uygulanacak şüpheli olguların sayısı azalmaktadır. ${ }^{46]}$

Protez enfeksiyonlarının tanısında AMAs, İLs ile benzer doğrulukta kullanılabilir. İki yöntemi protez enfeksiyonu tanısı için direkt karşılaştıran bir çalışma olmasa da yapılan bir meta-analizde AMAs için duyarlılık $\% 83$, özgüllük \%79 olarak bildirilmiştir. ${ }^{[33]}$ Nispeten düşük özgüllük olmakla birlikte İLs'ye alternatif olarak kullanılabileceği belirtilmiştir. ${ }^{[46]}$ İLs için tanımlanmış görüntüleme ve yorumlama standartları AMAs için de kullanılabilir. ${ }^{[14]}$ İşaretli antikorların kemik iliğinde işaretli lökositlere göre daha fazla tutulması Kis'nin referans olarak kullanılmasını zorlaştırır. Ayrıca aseptik gevşemede antikorlar ekstravasküler sızıntı nedeni ile enflamasyon alanında birikerek yanlış pozitif sonuçlara neden olabilirler. ${ }^{[54]}$

Hangi radyofarmasötik kullanılırsa kullanılsın SPECT/ BT eklemek, kemik enfeksiyonunu yumuşak dokudan daha iyi ayırt ederek protez enfeksiyonunun tanısal doğruluğunu artırır. Yapılan bir çalışmada İLs'nde planar görüntülere SPECT/BT eklendiğinde duyarlılığın \%82'den, özgüllüğün \%88'den ve doğruluğun \%84'den \%93'e yükseldiği, ayrıca kalça protezlerinde diz protezine göre daha fazla katkı sağladığı gösterildi. ${ }^{[55]}$

FDG PET, enfeksiyon görüntülemede giderek artan sıklıkta kullanılmaktadır. Protez enfeksiyonlarının tanısında FDG PET'in rolünü araştıran çalışmalar değişken ve bazen de çelişkili sonuçlar vermiştir. EANM/SNMMI (Nükleer tıp ve moleküler görüntüleme derneği) ortak kılavuzuna göre diz ve kalça protez enfeksiyonları için \%95 genel duyarlılık, \%98 özgüllük ve \%78 tanısal doğruluk bildirilmiştir. ${ }^{[27]}$ Sistemik derlemelerde duyarlılık (\%28-91) ve özgüllük (\%34-97) oldukça geniş bir aralıkta değişmektedir. Bu değişkenliğin nedeni hem çalışma tasarımlarındaki farklılıklardan hem de standartlaştırılmamış ve farklı yorumlama kriterlerinin kullanılmasından kaynaklanmaktadır. FDG tutulum paternine göre görsel yorumlamayı esas alan Reinartz ve ark.'nın tanımladığı kriterlerin kullanıldığı çalışmalarda özellikle yüksek duyarlılık ve hassasiyet bildirilmiştir. ${ }^{[56,57]}$ Buna göre herhangi bir artmış tutulum olmaması, femur boynuna eşlik eden asetabular çatının veya proksimal şaftın bir kısmında protez ile kemik arasında artmış FDG tutulumu olması aseptik gevşeme olmadığını göstermektedir. Femur boynuna eşlik eden asetabular çatının tamamında veya şaftın büyük kısmında protez ile kemik arasında artmış FDG tutulumu olması durumunda aseptik gevşeme olarak değerlendirilmektedir. Protez etrafindaki yumuşak dokuda artmış FDG tutulumunun diğer herhangi bir paterne eşlik etmesi ise enfeksiyon olarak değerlendirilir (Şekil 6). ${ }^{[56]}$ Kriter 

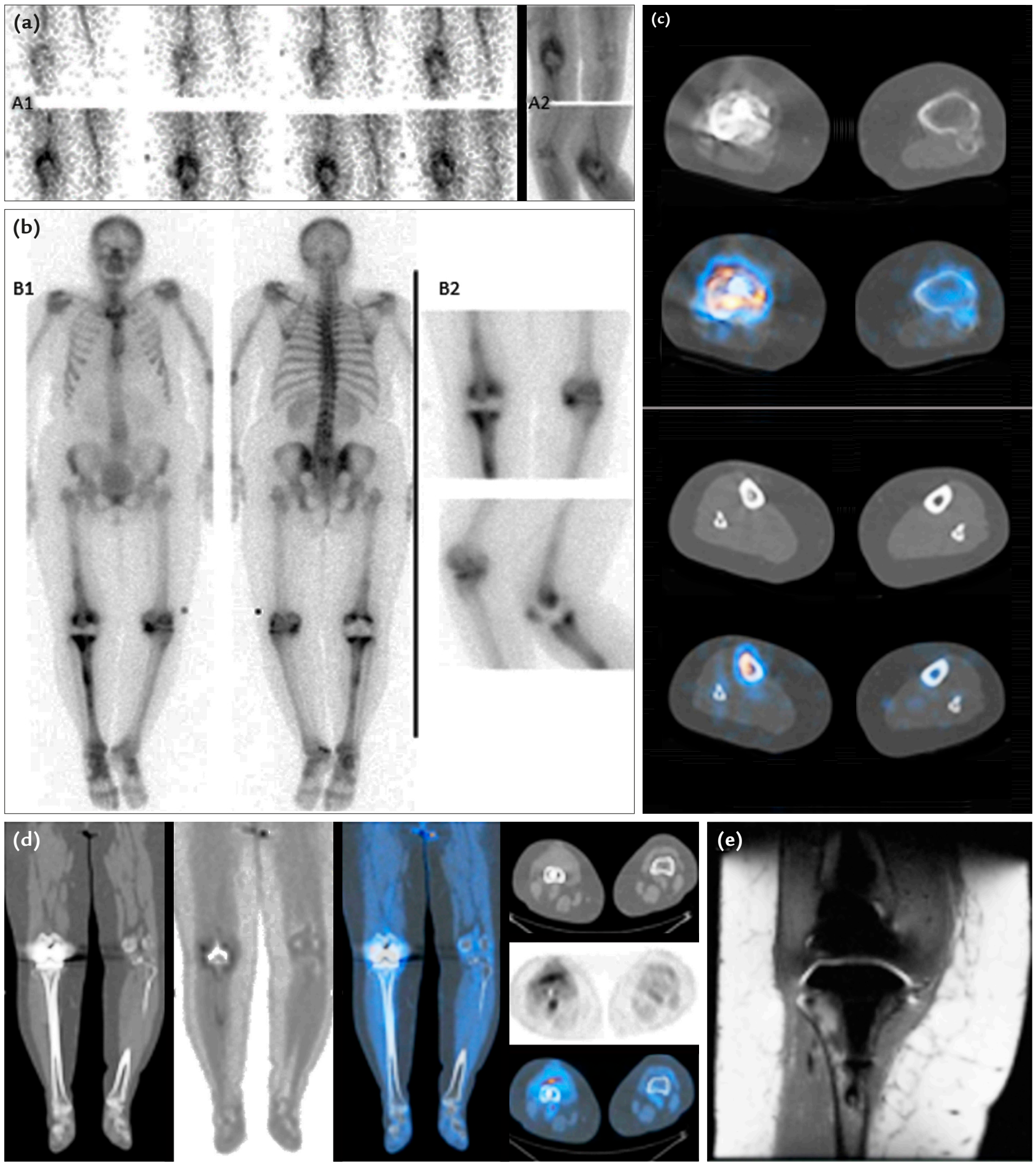

Şekil 6. a-e. Altmış yaşında kadın hastada sağ diz artroplasti cerrahisinden altı ay sonra ağrı ve kızarıklık başlamış. Enfeksiyon şüphesi nedeniyle Tc-99m-MDP ile yapılan kemik sintigrafisinde (a) kan akımı (A1), kan havuzu (A2) safhaları ile geç statik kemik fazında (b) sağ diz ekleminde protez çevresinde enfeksiyon düşündüren artmış aktivite tutulumu mevcuttur (B1, B2). SPECT/BT çalışmasında (c) protezin femur komponenti çevresinde enfeksiyonla uyumlu artmış aktivite tutulumu ile protezin tibia komponentinde ek olarak gevşeme düşündüren fokal artmış tutulum izlendi. FDG PET/BT çalışmasında (d) sağ diz protezi proksimal kesiminde, sağ eksternal iliak, sağ inguinal ve sağ popliteal bölgede lenf nodlarında artmış FDG tutulumu izlenmiş olup; diz ekleminde protez enfeksiyonu ve buna bağlı gelişen reaktif lenf nodlarını düşündürmüştür. Protez distalindeki fokal tutulum gevşeme lehine yorumlanmıştır. MRG'de (e) sağ diz eklemindeki hafif derecede sinoviyal effüzyon, sinovyumda belirgin kalınlaşma ve hafif ama diffüz sinoviyal kontrast parlaklaşmasıyla karakterize görünüm non-spesifik sinovit olarak yorumlanmış, septik bir neden MRG ile ayırt edilememiştir. Enfeksiyon nedeniyle iki aşamalı revizyon cerrahisi uygulanan hastanın halen sağ dizinde şikâyeti yok. 
olarak SUVmax değerlerine dayanan kantitatif analizlerin kullanıldığı çalışmalarda ise düşük özgüllük ve hassasiyet oranları bildirilmiştir. ${ }^{[58,59]}$

FDG PET ile İLs'nin protez enfeksiyonunda tanısal performansını karşılaştıran az sayıda makale bulunup, görüntüleme protokolü ve yorumlama kriterlerine göre sonuçlar çok değişkendir. Yapılan derlemelerde FDG PET'in daha yüksek duyarlılığa, İLs'nin daha yüksek özgüllüğe sahip olduğu bildirilmiştir. Ayrıca kalça protezi için doğruluk diz protezinden daha yüksek bulunmuştur. ${ }^{[60]}$

FDG işaretli lökosit PET'in, fizyolojik kemik iliği tutulumu olmaması, yüksek uzaysal rezolüsyonu nedeni ile yüksek görüntü kalitesi gibi İLs'ye üstünlükleri vardır. F-18'in kısa yarı ömrü kısa sürede görüntüleme avantajı sağlasa da, uzun süre alan işaretleme tekniği için çok elverişli değildir. Ayrıca protez enfeksiyonlarında biyofilmin neden olduğu yavaş lökosit akümülasyonunu göstermek amacıyla geç (20-24. saat) görüntü alınmasına firsat vermez. Protez enfeksiyonlarında FDG işaretli lökosit PET/BT'nin rolünün araştırıldığı bir çalışmada duyarlılık \%93, özgüllük \%97 olarak bulunmuştur. ${ }^{[61]}$

\section{Diyabetik Ayak}

Diyabetik ayak, periferik nöropati, diyabetik vaskülopati, immun yanıtta bozulma gibi predispozan faktörlerin etkisi ile malleol altında kalan kemik veya yumuşak dokuda oluşan enfeksiyonlara verilen addır. Travma dışı nedenlerle yapılan alt ekstremite amputasyonlarının yarısından fazlasının nedeni diyabetik ayak enfeksiyonları olup bir diyabet hastasının ömrü boyunca ayak ülseri geçirme riski \%15-25 arasında değişmektedir. Enfeksiyonlar genellikle ülserle başlar, $\% 72$ hastada osteomiyelit gelişir ve zamanında tanı ve tedavi almazsa hayatı tehdit eden ciddiyete ulaşabilir. Diyabet hastaları ağır bir osteomiyelit geçirdiklerinde dahi klinik sistemik yeterli enflamatuvar yanıt oluşturamadıklarından klinik bulgular silik olabilir. Diyabetik hastalarda ayakta kan akışında azalma olduğundan eritem ve endürasyon maskelenebilir. Ülser alanının 2 $\mathrm{cm}^{2}$ 'den büyük olması \%92 özgüllükle osteomiyelite işaret eder. 'Probe to bone' testi künt ve steril bir probla ülser içinden kemiğin muayene edilmesine dayanan kolay bir yöntem olup osteomiyeliti \%91 doğrulukla gösterir. Ancak ülser alanı büyüklügüüün de 'probe to bone' testinin de duyarlılığı düşük olup tanıyı ekarte ettirmez. Diyabetik ayak enfeksiyonlarında görüntüleme tanının vazgeçilmez bir parçasıdır. Diğer tüm kas-iskelet sistemi enfeksiyonlarında olduğu gibi görüntülemeden beklenen enfeksiyonun tanısını doğru olarak yapabilmesi ve kemik enfeksiyonlarını yumuşak doku enfeksiyonlarından ayırt edebilmesidir. Ancak nöropatik osteoartropati (Charcot eklemi) klinik ve radyolojik olarak osteomiyeliti taklit ederek tanıda güçlük oluşturur. Nöropatiye bağlı yumuşak doku enflamasyonu, kemik ve eklemde hızlı ve ilerleyici destrüksiyon, ayak arkında çökme, beşik ayak gelişimi ve bazen de ülserlerle karakterize nöropatik osteoartropati çoğunlukla ayağın orta ve arka kısmını ilgilendirir. Diyabetik ayak enfeksiyonu ise sıklıkla ülserle birliktelik gösterir ve genellikle ayağın ön kısmında prezente olur. İki klinik durumun birlikteliği de olabilir.

Direk grafiler genellikle tanı koydurucu olmasa da kolay uygulanması, ucuz olması, mevcut anatomik durumun tespiti ve sonraki prosedürleri yönlendirmesi nedeni ile ilk tercih edilecek görüntüleme yöntemidir. MRG mükemmel yumuşak doku rezolüsyonu ile diyabetik ayak osteomiyelitinde en uygun yöntem olduğu savunulmuştur. ${ }^{[62]}$ Ancak nöropatik osteoartropati veya geçirilmiş cerrahi gibi kemik iliği ödemi olan durumlarda MRG'nin özgüllüğü azalmaktadır. Duyarlılık (\%82-95), özgüllük \%62-91, tanısal doğruluk \%57'dir. ${ }^{[63]}$

ÜFKs; diyabetik ayak osteomiyeliti tanısında \%75100 gibi yüksek bir duyarlılığa sahipken, diyabet hastalarında sık görülen fraktür, nöropatik osteoartropati ve yumuşak doku enfeksiyonu gibi osteomiyeliti taklit eden durumlar nedeni ile spesifite oldukça düşüktür (\%0-59). ${ }^{[2]} 24$. saat görüntülemenin eklenerek görüntülemenin dört fazlı hale getirilmesinin özgüllügüü artıracağı düşünülmüşse de rutin kullanıma geçmesi için yeterli sonuçlar elde edilememiştir (Şekil 7). ${ }^{[64]}$

In-İLs, diyabetik ayak enfeksiyonu tanısında \%72-100 duyarlılığa, \%67-100 özgüllüğe Tc-íLs ise \%86- \%93 duyarlılığa, \%80-98 özgüllüğe sahiptir. ${ }^{[65]}$ In-ILs'de SPECT/BT doğruluğu artırsa bile yine de yumuşak doku enfeksiyonunu osteomiyelitten ayıramayabilir. Tc-íLs'ye SPECT/BT eklenmesi ile de tanısal doğruluğun arttığı bildirilmiştir. Ayrıca Erdman ve ark., Tc-ILLs'ye SPECT/BT'de anatomik ve fonksiyonel bilgileri skorlayarak Composite Severity Index (CSI) skorlama sistemini geliştirilmiş, elde edilen sonucun tanısal ve prognostik bilgi sağladığını göstermişlerdir. ${ }^{[66]}$

Dual izotop çalışmaları ise (ILs SPECT/BT/kemik sintigrafisi SPECT/BT) diyabetik ayak enfeksiyonu tanısında \%97 duyarlılık, \%94 özgüllük, \%97 doğruluğa sahiptir (Şekil 8). ${ }^{[63]}$ Ayrıca bu protokolde orta veya arka ayakta şüpheli osteomiyelit bulguları olan hastalara ikinci basamak olarak dual izotop ILs SPECT/BT/ kemik iliği SPECT/BT görüntülemenin eklenmesi nöropatik osteoartropatide görülen non-spesifik tutulumun doğru tespitinde oldukça yararlıdır. Dual izotop SPECT/ BT'nin hasta yönetiminde oldukça yararlı olduğu 459 hastayı içeren geniş kapsamlı bir çalışma ile gösterilmiştir. Bu çalışmada dual izotop kullanımının konvansiyonel görüntüleme yöntemleri (direkt grafi, BT, planar ÜFKs, planar İLs ve MRG) ile karar verilen gruba kıyasla 

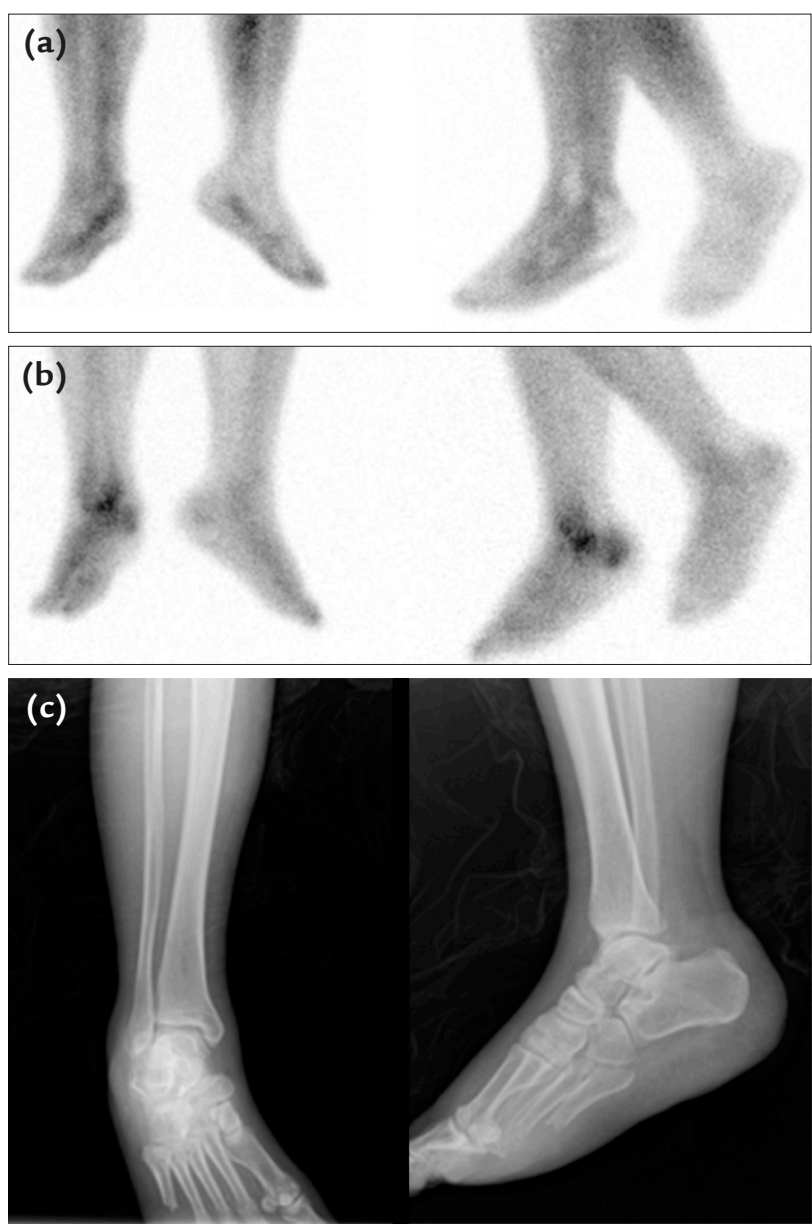

Şelkil 7. a-c. Altmış bir yaşında Tip 2 DM'li hastada fizik muayenede sağ ayakta $3 \mathrm{~cm}$ çapında ülsere cilt lezyonu ve "rocker bottom" (beşik ayak) deformitesi mevcuttu. Sağ ayak 5. parmak ve 5. metatarsal kemiğin bir kısmı ampute görünümdeydi. ÜFKs kan havuzu fazında (a) sağ ayak ve ayak bileğinde cilt lezyonu ile uyumlu minimal hiperemi mevcut. Geç dönemde alınan spot görüntülerde (b) sağ ayak bileğinde (tibia distali ve talusda periartriküler paternde) ve kalkaneusda artropati ile uyumlu artmış radyoaktivite tutulumları görülmekte. Direkt grafilerde (c) 5. metatars kemik ampute görünümde olup vasküler kalsifikasyon izleniyor. Tibiotalar ve talokalkaneal eklemlerde ise minimal dejeneratif artrit bulguları ve kalkaneusda spur formasyonu görülmekte. (Prof. Dr. Nuri Arslan'a teşekkür ederiz.)

majör amputasyon oranlarında önemli bir düşüş sağladığı gösterilmiştir (\%3,7’ye karşııı \%7). ${ }^{[67]}$ Aynı şekilde hastanede yatış süreleri de dual izotop SPECT/BT uygulanan grupta, konvansiyonel görüntüleme yöntemlerinin uygulandığı gruba göre anlamlı derecede düşüktü (6,8 güne karşılık 9,3 gün). Bu durum her ne kadar dual izotop görüntülemenin tamamlanma süresi uzun olsa da; konvansiyonel görüntüleme yöntemlerine göre yönetim kararını kısalttığını düşündürmektedir. ${ }^{[67]}$
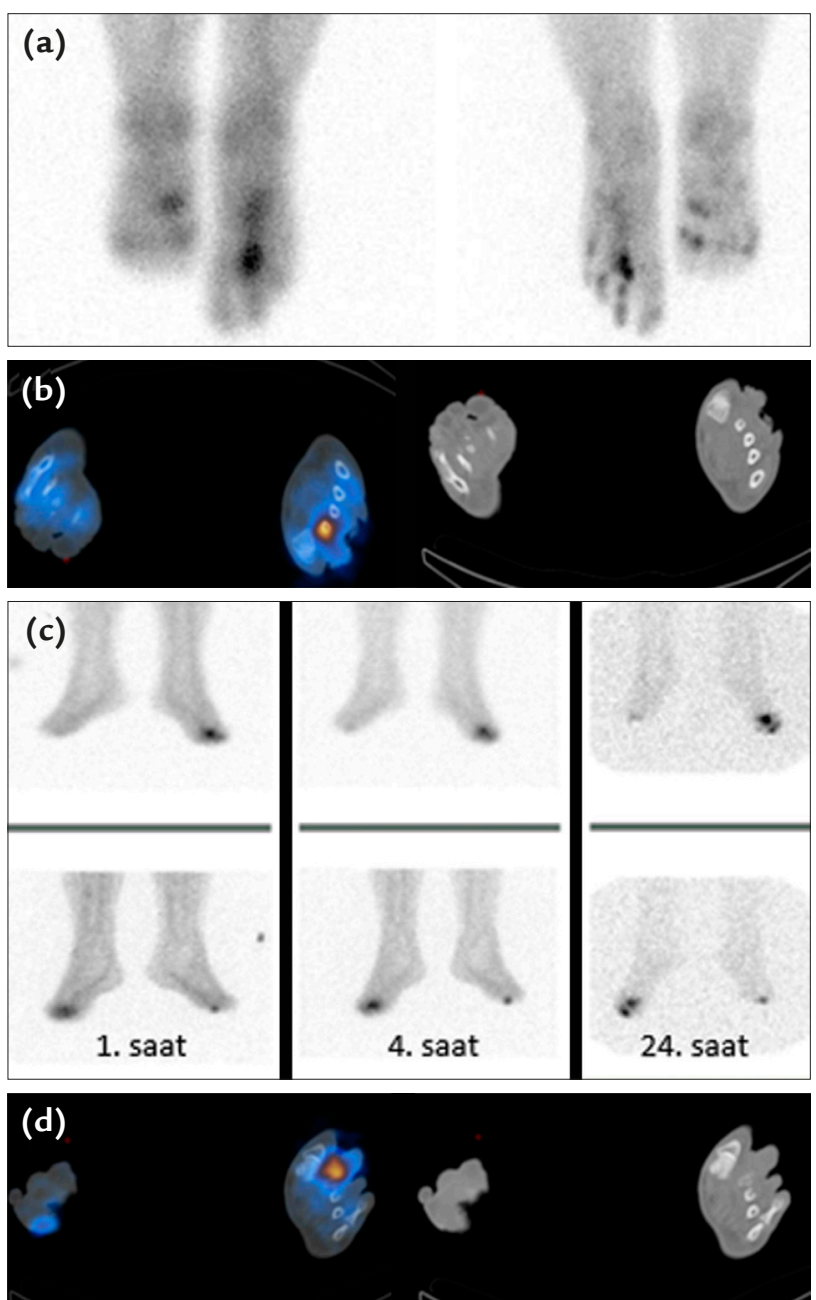

Şekil 8. a-d. Kırk yaşında DM'li erkek hastada dual izotop (ÜFKs SPECT/BT+iLs SPECT/BT) çalışması. Daha önce diyabetik ayak enfeksiyonu nedeni ile sol ayak 3. parmağı ampute edilmiş olan hasta osteomiyelit ön tanısı ile tetkik edilmiş. ÜFKs geç statik görüntüde (a) ve kemik sintigrafisi SPECT/ BT'de (b) sol ayak 2. metatarsta kortikal düzensizlik, kalınlaşma ve artmış radyoaktivite tutulumu izlenmekte. ILs'de 1., 4. ve 24. saatte alınan statik görüntülerde (c) ve SPECT/BT görüntüsünde (d), kemik sintigrafisinde tutulum olan alanda osteomiyelitle uyumlu olarak yoğun artmış radyoaktivite tutulumu izlenmektedir. (Prof. Dr. Nuri Arslan'a teşekkür ederiz.)

İLs SPECT/BT'nin diyabetik ayak osteomiyelitinde tedaviye yanıt değerlendirilmesinde de yararlı bir tetkik olabileceği, negatif bir testin remisyonu gösterdiği ve relaps ihtimalini yüksek oranda dışladığı gösterilmiştir. Yapılan bir çalışmada 6 veya 12 haftalık antibiyotik tedavisi tamamlandıktan sonra yapılan Tc-99 m işaretli íLs SPECT/BT, osteomiyelit relapsını öngörmede \%100 duyarlılık, \%56 özgüllük, \%100 negatif öngörü değeri ve $\% 46$ pozitif öngörü değeri göstermiştir. ${ }^{[68]}$ 
Nöropatik osteoartropatide etkilenen kemikte hematopoetik olarak aktif olan kemik iliğine bağlı işaretli lökosit tutulumu olur. İLs'ye tamamlayıcı olarak Kìs eklenerek kemik iliği aktivitesi enfeksiyondan ayırt edilebilir. Yapılan bir çalışmada planar İLs/Kís'nin \%95 doğruluk oranı ile enfeksiyonu gösterdiği bildirilmiştir. ${ }^{[69]}$ Planar Tc-99 m İLs/dört fazlı kemik sintigrafisinin diyabetik ayak osteomiyelitini \%92 doğrulukla tespit ettiği başka bir çalışmada gösterilmiştir. ${ }^{[70]}$

AMAs ile yapılan çalışmalar İLs'ye yakın sayılabilecek sonuçlar vermiştir. Tc-99 m besilesomabla yapılan bir çalışmada \%93 duyarlılık, \%78 özgüllük \%84 doğruluk bildirilmiştir. ${ }^{[71]}$

FDG PET ve FDG PET/BT'nin diyabetik ayak enfeksiyonlarının değerlendirmedeki rolü halen belirsizdir. Birçok çalışmada bu konu araştırılmış ve değişken sonuçlar elde edilmiştir. Bu durumun nedeni, araştırmacıların görsel değerlendirme, SUVmax ölçümüne dayanan kantitatif değerlendirme gibi farklı yorumlama kriterleri kullanması, vasküler yetmezlik olup olmaması gibi popülasyonlar arasındaki farklar, hastaların aldıkları tedaviler gibi faktörlerden kaynaklanmış olması muhtemeldir. Basu ve ark., FDG PET'in diyabetik osteomiyeliti ve nöropatik osteoartropatiyi göstermede \%100 duyarlılık ve \%93,8 özgüllüğe sahip olduğunu; MRG için ise bu değerleri sırasıly $\% 76,9$ ve $\% 75$ bulduklarını bildirdiler. SUVmax değerlerini nöropatik osteoartropatide $0,7-2,4$ aralığında, osteomiyelitte ise tipik olarak 2,5'un üzerinde (2,9-6,2 aralığında) buldular. ${ }^{[72]}$ Nawaz ve ark. ise 110 hastayla yaptıkları ileriye dönük çalışmada; FDG PET'in \%81 duyarlıık, \%93 özgüllük ve \%90 doğruluğa; MRG'nin ise \%91 duyarlılık, \%78 özgüllük, \%81 doğruluğa sahip olduğunu gösterdiler. FDG PET'in diyabetik ayak osteomiyelitinde oldukça spesifik bir görüntüleme yöntemi olduğunu ve MRG'ye yararlı bir tamamlayıcı olarak kabul edilmesi gerektiği sonucuna vardılar. ${ }^{[73]}$ FDG PET/BT'nin diyabetik ayak osteomiyeliti tanısındaki değerini araştıran bir meta-analizde ise duyarlılık \%74 (\%95 güven aralığında \%60-85); özgüllük \%91 (\%95 güven aralığında \%85-96) olarak tespit edilmiştir. ${ }^{[74]}$

FDG PET/BT ile planar Tc-99 m İLs'nin karşılaştırıldığı 13 hastayı içeren bir çalışmada diyabetik ayak osteomiyelitini göstermede FDG PET'in \%54 doğruluğu olduğu, BT bulgularının eklenmesi ile doğruluğun \%62'ye çıtı̆̆ını, halbuki planar íLs'nin \%92 doğruluk gösterdiğini buldular. Yazarlar, FDG PET/BT'nin diyabetik ayak osteomiyelitini doğru bir şekilde gösteremediği ve İLs'nin yerine geçemeyeceği sonucuna vardılar. ${ }^{[75]}$

FDG PET çalışmalarında, diyabetik hastalardaki yüksek kan glukoz düzeylerinin FDG tutulumunu engelleyerek osteomiyelit tanısını zorlaştırabileceği endişesi olsa da yapılan çalışmalarda onkolojik çalışmaların aksine enfeksiyon ve enflamasyon tanısında buna atfedilen herhangi bir yanlış negatiflik tanımlanmamıştır. ${ }^{[76]}$

\section{KAYNAKLAR}

1. Glaudemans AW, Prandini N, DI Girolamo M, Argento G, Lauri C, Lazzeri E, Muto M, Sconfienza LM, Signore A. Hybrid imaging of musculoskeletal infections. Q J Nucl Med Mol Imaging 2018;62(1):3-13. Crossref

2. Palestro CJ. Radionuclide imaging of musculoskeletal infection: A Review. J Nucl Med 2016;57(9):1406-12. Crossref

3. Love C, Palestro CJ. Nuclear medicine imaging of bone infections. Clin Radiol 2016;71(7):632-46. Crossref

4. Ertay T. Enfeksiyon-inflamasyon: moleküler görüntülemede kullanılan SPECT radyofarmasötikleri. Nucl Med Semin 2016;2:63-70. Crossref

5. Ömür Ö, Kapulu C, Uğur Ö. Kas-iskelet sistemi hastalıklarında nükleer tıp yöntemleri. TOTBiD Derg 2007;6(1-2):1-29. http://dergi.totbid.org.tr/files/6_1-2/2.pdf

6. Palestro CJ. Radionuclide imaging of osteomyelitis. Sem Nucl Med 2015;45(1):32-46. Crossref

7. Palestro CJ, Love C. Radionuclide imaging of musculoskeletal infection: conventional agents. Semin Musculoskelet Radiol 2007;11(4):335-52. Crossref

8. Hoffer P. Gallium and infection. J Nucl Med 1980;21:484-8. http://jnm.snmjournals.org/content/21/5/484.long

9. Palestro CJ, Love C, Tronco GG, Tomas MB, Rini JN. Combined labeled leukocyte and technetium-99m sulphur colloid marrow imaging for diagnosing musculoskeletal infection: principles, technique, interpretation, indications and limitations. Radio Graphics 2006;26(3):859-70. Crossref

10. Glaudemans AWJM, de Vries EFJ, Vermeulen LEM, Slart RHJA, Dierckx RAJO, Signore A. A large retrospective single centre study to define best image acquisition protocols and interpretation criteria for white blood cell scintigraphy with 99Tc- HMPAO labelled leukocytes in musculoskeletal infections. Eur J Nucl Med Mol Imaging 2013;40:1760-9. Crossref

11. Miron S, Minotti A, Crass J. Accumulation of In-111 tagged white blood cells in heterotopic new bone. Clin Nucl Med 1992;17(12):972-3. Crossref

12. Kim EE, Pjura GA, Lowry PA, Gobuty $A H$, Traina JE. Osteomyelitis complicating fracture: pitfalls of 111-In leukocyte scintigraphy. AJR Am J Roentgenol 1987;148(5):927-30. Crossref

13. Palestro CJ, Love C, Bhargava KK. Labeled leukocyte imaging: current status and future directions. Q J Nucl Med Mol Imaging 2009;53(1):105-23.

14. Signore A, Jamar F, Israel O, Buscombe J, Martin-Comin J, Lazzeri E. Clinical indications, image acquisition and data interpretation for white blood cells and anti-granulocyte monoclonal antibody scintigraphy: an EANM procedural guideline. Eur J Nucl Med Mol Imaging 2018;45(10):181631. Crossref

15. Palestro CJ, Glaudemans AWJM, Dierckx RAJO. Multiagent imaging of inflammation and infection with radionuclides. Clin Transl Imaging 2013;1(6):385-96. Crossref

16. Lazzeri E, Signore A, Erba PA, Prandini N, Versari A, D’Errico G, Mariani G. Radionuclide imaging of infection and inflammation. A pictorial case-based atlas. Italy: SpringerVerlag Italia; 2013. p.7. Crossref 
17. Naqvi SAR, Roohi S, Sabir H, Shahzad SA, Aziz A, Rasheed R. Susceptibility of $99 \mathrm{mTc}$-ciprofloxacin for common infection causing bacterial strains isolated from clinical samples: an in vitro and in vivo study. Appl Biochem Biotechnol 2019;188(2):424-35. Crossref

18. Kiamanesh Z, Ayati N, Alavi R, Gharehdaghi M, Aryana K. Application of $99 \mathrm{mTc}-\mathrm{UBI} 29-41$ scintigraphy in knee periprosthetic infection diagnosis. Nuklearmedizin 2019;58(4):301-8. Crossref

19. Kjaer A, Lebech AM, Eigtved A, Hojgaard L. Fever of unknown origin: prospective comparison of diagnostic value of 18F-FDG PET and 111 In-granulocyte scintigraphy. Eur J Nucl Med Mol Imaging 2004;31(5):622-6. Crossref

20. Yilmaz S, Aliyev A, Ekmekcioglu O, Ozhan M, Uslu L, Vatankulu B, Sager S, Halaç M, Sönmezoglu K. Comparison of FDG and FDG-labeled leukocytes PET/CT in diagnosis of infection. Nuklearmedizin 2015;54(6):262-71. Crossref

21. Ebenhan T, Zeevaart JR, Venter JD, Govender T, Kruger GH, Jarvis NV, Sathekge MM. Preclinical evaluation of $68 \mathrm{Ga}-$ labeled 1, 4, 7-triazacyclononane1, 4, 7-triacetic acid ubiquicidin as a radioligand for PET infection imaging. J Nucl Med 2014;55(2):308-14. Crossref

22. Diaz LA Jr, Foss CA, Thornton K, Nimmagadda S, Endres CJ, Uzuner O, Seyler TM, Ulrich SD, Conway J, Bettegowda C, Agrawal N, Cheong I, Zhang X, Ladenson PW, Vogelstein BN, Mont MA, Zhou S, Kinzler KW, Vogelstein B, Pomper MG. Imaging of musculoskeletal bacterial infections by [124I] FIAU-PET/CT. PLoS One 2007;2(10):e1007. Crossref

23. Zhang XM, Zhang HH, McLeroth $P$, Berkowitz RD, Mont MA, Stabin MG, Siegel BA, Alavi A, Barnett TM, Gelb J, Petit C, Spaltro J, Cho SY, Pomper MG, Conklin JJ, Bettegowda C, Saha S. [124I] FIAU. Human dosimetry and infection imaging in patients with suspected prosthetic joint infection. Nucl Med Biol 2016;43(5):273-9. Crossref

24. Glaudemans AWJM, Jutte PC, Cataldo MA, Cassar-Pullicino V, Gheysens O, Borens O, Trampuz A, Wörtler K, Petrosillo N, Winkler H, Signore A, Sconfienza LM. Consensus document for the diagnosis of peripheral bone infection in adults: a joint paper by the EANM, EBJIS, and ESR (with ESCMID endorsement). EurJ Nucl Med Mol Imaging 2019;46(4):95770. Crossref

25. Thang SP, Tong AKT, Lam WWC, Ng DCE. SPECT/CT in musculoskeletal infections. Semin Musculoskelet Radiol 2014;18(2):194-202. Crossref

26. Glaudemans AWJM, Signore A. FDG-PET/CT in infections: the imaging method of choice? Eur J Nucl Med Mol Imaging 2010;37(10):1986-91. Crossref

27. Jamar F, Buscombe J, Chiti A, Christian PE, Delbeke D, Donohoe KJ, Israel O, Martin-Comin J, Signore A. EANM/ SNMMI guideline for 18F-FDG use in inflammation and infection. J Nucl Med 2013;54(4):647-58. Crossref

28. Darge K, Jaramillo D, Siegel MJ. Whole-body MRI in children: current status and future applications. Eur J Radiol 2008;68(2):289-98. Crossref

29. Govaert GA, IJpma FF, McNally M, McNally E, Reininga IH, Glaudemans AW. Accuracy of diagnostic imaging modalities for peripheral post-traumatic osteomyelitis - a systematic review of the recent literature. Eur J Nucl Med Mol Imaging 2017;44(8):1393-407. Crossref

30. Loessel C, Mai A, Starke M, Vogt D, Stichling M, Willy C. Value of antigranulocyte scintigraphy with Tc-99m-sulesomab in diagnosing combat-related infections of the musculoskeletal system. J R Army Med Corps 2019;0:1-10. Crossref

31. Demirev A, Weijers R, Geurts J, Mottaghy F, Walenkamp G, Brans B. Comparison of 18F-FDG PET/CT and MRI in the diagnosis of acute osteomyelitis. Skelet Radiol 2014;43(5):665-72. Crossref
32. Raghavan $M$, Lazzeri $E$, Palestro CJ. Imaging of spondylodiscitis. Semin Nucl Med 2018;48(2):131-47. Crossref

33. Berbari EF, Kanj SS, Kowalski TJ, Darouiche RO, Widmer AF, Schmitt SK, Hendershot EF, Holtom PD, Huddleston PM 3rd, Petermann GW, Osmon DR. Infectious Diseases Society of America 2015 Infectious Diseases Society of America (IDSA) clinical practice guidelines for the diagnosis and treatment of native vertebral osteomyelitis in adults. Clin Infect Dis 2015;61(6):e26-46. Crossref

34. Lazzeri E, Bozzao A, Cataldo MA, Petrosillo N, Manfrè L, Trampuz A, Signore A, Muto M. Joint EANM/ESNR and ESCMID-endorsed consensus document for the diagnosis of spine infection (spondylodiscitis) in adults. Eur J Nucl Med Mol Imaging 2019;46(12):2464-87. Crossref

35. Prandini N, Lazzeri E, Rossi B, Erba P, Parisella MG, Signore A. Nuclear medicine imaging of bone infections. Nucl Med Commun 2006;27(8):633-44. Crossref

36. Fuster $D$, Solà $O$, Soriano A, Monegal A, Setoain X, Tomás X, Garcia S, Mensa J, Rubello D, Pons F. A prospective study comparing whole-body FDG PET/CT to combined planar bone scan with 67Ga SPECT/CT in the diagnosis of spondylodiskitis. Clin Nucl Med 2012;37(9):827-32. Crossref

37. Lazzeri E, Erba P, Perri M, Tascini C, Doria R, Giorgetti J, Mariani G. Scintigraphic imaging of vertebral osteomyelitis with 111 in-biotin. Spine 2008;33(7):E198-204. Crossref

38. Kim SJ, Pak K, Kim K, Lee JS. Comparing the Diagnostic Accuracies of F-18 Fluorodeoxyglucose Positron Emission Tomography and Magnetic Resonance Imaging for the Detection of Spondylodiscitis: A Meta-analysis. Spine 2019;44(7):E414-22. Crossref

39. Hungenbach S, Delank KS, Dietlein M, Eysel P, Drzezga A, Schmidt MC. 18F-fluorodeoxyglucose uptake pattern in patients with suspected spondylodiscitis. Nucl Med Commun 2013;34(11):1068-74. Crossref

40. Fahnert J, Purz S, Jarvers JS, Heyde CE, Barthel H, Stumpp P, Kahn T, Sabri O, Friedrich B. Use of simultaneous 18F-FDG $\mathrm{PET} / \mathrm{MRI}$ for the detection of spondylodiskitis. J Nucl Med 2016;57(9):1396-401. Crossref

41. De Winter F, Gemmel F, Van De Wiele C, Poffijn B, Uyttendaele D, Dierckx R. 18-fluorine fluorodeoxyglucose positron emission tomography for the diagnosis of infection in the postoperative spine. Spine 2003;28(12):1314-9. Crossref

42. Inanami $H$, Oshima $Y$, Iwahori $T$, Takano $Y$, Koga $H$, Iwai $\mathrm{H}$. Role of $18 \mathrm{~F}$-fluoro-deoxyglucose PET/CT in diagnosing surgical site infection after spine surgery with instrumentation. Spine 2015;40(2):109-13. Crossref

43. Riccio SA, Chu AK, Rabin HR, Kloiber R. Fluorodeoxyglucose positron emission tomography/computed tomography interpretation criteria for assessment of antibiotic treatment response in pyogenic spine infection. Can Assoc Radiol J 2015;66(2):145-52. Crossref

44. Cataldo MA, Petrosillo N, Cipriani M, Cauda R, Tacconelli E. Prosthetic joint infection: recent developments in diagnosis and management. J Inf Secur 2010;61(6):443-8. Crossref

45. Parvizi J, Tan TL, Goswami K, Higuera C, Della Valle C, Chen AF, Shohat N. The 2018 Definition of Periprosthetic Hip and Knee Infection: An Evidence-Based and Validated Criteria. J Arthroplasty 2018;33(5):1309-14.e2. Crossref

46. Signore A, Sconfienza LM, Borens O, Glaudemans AWJM, Cassar-Pullicino V, Trampuz A, Winkler $H$, Gheysens $O$, Vanhoenacker FMHM, Petrosillo N, Jutte PC. Consensus document for the diagnosis of prosthetic joint infections: a joint paper by the EANM, EBJIS, and ESR (with ESCMID endorsement). EurJ Nucl Med Mol Imaging 2019;46(4):97188. Crossref 
47. Bingham J, Clarke H, Spangehl M, Schwartz A, Beauchamp C, Goldberg B. The alpha defensin-1 biomarker assay can be used to evaluate the potentially infected total joint arthroplasty. Clin Orthop Relat Res 2014;472(12):4006-9. Crossref

48. Parvizi J, Zmistowski B, Berbari EF, Bauer TW, Springer BD, Della Valle CJ, Garvin KL, Mont MA, Wongworawat MD, Zalavras CG. New definition for periprosthetic joint infection: from the Workgroup of the Musculoskeletal Infection Society. Clin Orthop Relat Res 2011;469(11):2992-4. Crossref

49. Talbot BS, Weinberg EP. MR imaging with metal-suppression sequences for evaluation of total joint arthroplasty. Radiographics 2016;36(1):209-25. Crossref

50. Wilson MA. Musculoskeletal system. In: Wilson MA, editor. Textbook of Nuclear Medicine. Philadelphia: New York, Lippincott-Raven; 1997. p.3-32.

51. Trevail C, Ravindranath-Reddy P, Sulkin T, Bartlett G. An evaluation of the role of nuclear medicine imaging in the diagnosis of periprosthetic infections of the hip. Clin Radiol 2016;71(3):211-9. Crossref

52. Pelosi E, Baiocco C, Pennone M, Migliaretti G, Varetto T, Maiello A, Bellò M, Bisi G. 99mTc-HMPAO-leukocyte scintigraphy in patients with symptomatic total hip or knee arthroplasty: improved diagnostic accuracy by means of semiquantitative evaluation. J Nucl Med 2004;45(3):438-44. http://jnm.snmjournals.org/content/45/3/438.full.pdf

53. Xing $\mathrm{D}, \mathrm{Ma} X, \mathrm{Ma} J$, Wang J, Chen $\mathrm{Y}$, Yang $\mathrm{Y}$. Use of antigranulocyte scintigraphy with $99 \mathrm{mTc}$-labeled monoclonal antibodies for the diagnosis of periprosthetic infection in patients after total joint arthroplasty: a diagnostic metaanalysis. PLoS One 2013;8(7):e69857. Crossref

54. Yaylalı O. Ortopedik protez enfeksiyonlarında moleküler görüntüleme yöntemlerinin rolü. Nucl Med Semin 2016;4:11021. Crossref

55. Kim $\mathrm{HO}, \mathrm{Na} \mathrm{SJ}$, Oh $\mathrm{SJ}$, Jung BS, Lee $\mathrm{SH}$, Chang JS, Bin SI, Ryu JS. Usefulness of adding SPECT/CT to 99mTchexamethylpropylene amine oxime (HMPAO)-labeled leukocyte imaging for diagnosing prosthetic joint infections. J Comput Assist Tomogr 2014;38(2):313-9. Crossref

56. Reinartz $\mathrm{P}$, Mumme T, Hermanns B, Cremerius U, Wirtz DC, Schaefer WM, Niethard FU, Buell U. Radionuclide imaging of the painful hip arthroplasty: positron-emission tomography versus triple-phase bone scanning. J Bone Joint Surg $\mathrm{Br}$ 2005;87-B(4):465-70. Crossref

57. Chacko TK, Zhuang H, Stevenson K, Moussavian B, Alavi A. The importance of the location of fluorodeoxyglucose uptake in periprosthetic infection in painful hip prostheses. Nucl Med Commun 2002;23(9):851-5. Crossref

58. Stumpe KD, Nötzli HP, Zanetti M, Kamel EM, Hany TF, Görres GW, von Schulthess GK, Hodler J. FDG PET for differentiation of infection and aseptic loosening in total hip replacements: comparison with conventional radiography and three-phase bone scintigraphy. Radiology 2004;231(2):333-41. Crossref

59. García-Barrecheguren E, Rodríguez Fraile M, Toledo Santana G, Valentí Nín JR, Richter Echevarría JA. FDG-PET. a new diagnostic approach in hip prosthetic replacement. Rev Esp Med Nucl 2007;26(4):208-20. Crossref

60. Reinartz P. FDG-PET in patients with painful hip and knee arthroplasty: technical breakthrough or just more of the same. Q J Nucl Med Mol Imaging 2009;53(1):41-50. https:// www.minervamedica.it/en/journals/nuclear-med-molecularimaging/article. php?cod=R39Y2009N01A0041

61. Aksoy SY, Asa S, Ozhan M, Ocak M, Sager MS, Erkan ME, Halac M, Kabasakal L, Sönmezoglu K, Kanmaz B. FDG and FDG-labelled leucocyte PET/CT in the imaging of prosthetic joint infection. EurJ Nucl Med Mol Imaging 2014;41(3):55664. Crossref
62. Donovan A, Schweitzer ME. Use of MR imaging in diagnosing diabetes- related pedal osteomyelitis. Radiographics 2010;30(3):723-36. Crossref

63. Heiba $S$, Knešaurek $K$. Evaluation of diabetic foot infection in nuclear medicine. QJ Nucl Med Mol Imaging 2017;61(3):28391. Crossref

64. Alazraki N, Dries D, Datz F, Lawrence P, Greenberg E, Taylor A Jr. Value of a 24-hour image (four-phase bone scan) in assessing osteomyelitis in patients with peripheral vascular disease. J Nucl Med 1985;26(7):711-7. http://jnm. snmjournals.org/content/26/7/711.full.pdf

65. Palestro CJ. Molecular imaging of diabetic foot infections. Nucl Med Semin 2016;2:95-103. Crossref

66. Erdman WA, Buethe J, Bhore R, Ghayee HK, Thompson C, Maewal P, Anderson J, Klemow S, Oz OK. Indexing severity of diabetic foot infection with $99 \mathrm{mTc}-$ WBC SPECT/CT hybrid imaging. Diabetes Care 2012;35(9):1826-31. Crossref

67. Heiba S, Kolker D, Ong L, Sharma S, Travis A, Teodorescu V, Ellozy S, Kostakoglu L, Savitch I, Machac J. Dual-isotope SPECT/CT impact on hospitalized patients with suspected diabetic foot infection: saving limbs, lives, and resources. Nucl Med Commun 2013;34(9):877-84. Crossref

68. Vouillarmet J, Moret M, Morelec I, Michon P, Dubreuil J. Application of white blood cell SPECT/CT to predict remission after a 6 or 12 week course of antibiotic treatment for diabetic foot osteomyelitis. Diabetologia 2017;60(12):2486-94. Crossref

69. Palestro $\mathrm{CJ}$, Mehta $\mathrm{HH}$, Patel $\mathrm{M}$, Freeman SJ, Harrington WN, Tomas MB, Marwin SE. Marrow versus infection in the Charcot joint: indium-111 leukocyte and technetium-99m sulfur colloid scintigraphy. J Nucl Med 1998;39(2):346-50. http://jnm.snmjournals.org/content/39/2/346.full.pdf

70. Unal SN, Birinci H, Baktiroğlu S, Cantez S. Comparison of Tc-99m methylene diphosphonate, Tc-99m human immune globulin, and Tc-99m-labeled white blood cell scintigraphy in the diabetic foot. Clin Nucl Med 2001;26(12):1016-21. Crossref

71. Dominguez-Gadea L, Martin-Curto LM, de la Calle $H$, Crespo A. Diabetic foot infections: scintigraphic evaluation with 99Tcm-labelled anti-granulocyte antibodies. Nucl Med Commun 1993;14(3):212-8. Crossref

72. Basu S, Chryssikos T, Houseni M, Scot Malay D, Shah J, Zhuang $\mathrm{H}$, Alavi A. Potential role of FDG PET in the setting of diabetic neuroosteoarthropathy: can it differentiate uncomplicated Charcot's neuroarthropathy from osteomyelitis and softtissue infection? Nucl Med Commun 2007;28(6):465-72. Crossref

73. Nawaz A, Torigian DA, Siegelman ES, Basu S, Chryssikos T, Alavi A. Diagnostic performance of FDG-PET, MRI, and plain film radiography (PFR) for the diagnosis of osteomyelitis in the diabetic foot. Mol Imag Biol 2010;12(3):335-42. Crossref

74. Treglia G, Sadeghib R, Annunziata S, Zakavi SR, Caldarella C, Muoio B, Bertagna F, Ceriani L, Giovanella L. Diagnostic performance of fluorine- 18-fluorodeoxyglucose positron emission tomography for the diagnosis of osteomyelitis related to diabetic foot: a systematic review and a metaanalysis. Foot (Edinb) 2013;23(4):140-8. Crossref

75. Familiari D, Glaudemans AWJM, Vitale V, Prosperi D, Bagni O, Lenza A, Cavallini M, Scopinaro F, Signore A. Can sequential 18F-FDG PET/CT replace WBC imaging in the diabetic foot? J Nucl Med 2011;52(7):1012-9. Crossref

76. Rabkin Z, Israel O, Keidar Z. Do hyperglycemia and diabetes affect the incidence of false-negative 18F-FDG $P E T / C T$ studies in patients evaluated for infection or inflammation and cancer? A comparative analysis. J Nucl Med 2010;51(7):1015-20. Crossref 